\title{
Occurrence, toxicity and remediation of polyethylene terephthalate plastics. A review
}

\author{
Vaishali Dhaka ${ }^{1}$ - Simranjeet Singh ${ }^{2} \cdot$ Amith G. Anil $^{3} \cdot$ T. S. Sunil Kumar Naik ${ }^{2}$ - Shashank Garg ${ }^{1}$ - Jastin Samuel ${ }^{4}$. \\ Manoj Kumar $^{5}$. Praveen C. Ramamurthy ${ }^{2} \cdot$ Joginder Singh $^{1} \mathbb{C}$
}

Received: 16 August 2021 / Accepted: 29 December 2021 / Published online: 13 January 2022

(c) The Author(s), under exclusive licence to Springer Nature Switzerland AG 2022

\begin{abstract}
Polyethylene terephthalate is a common plastic in many products such as viscose rayon for clothing, and packaging material in the food and beverage industries. Polyethylene terephthalate has beneficial properties such as light weight, high tensile strength, transparency and gas barrier. Nonetheless, there is actually increasing concern about plastic pollution and toxicity. Here we review the properties, occurrence, toxicity, remediation and analysis of polyethylene terephthalate as macroplastic, mesoplastic, microplastic and nanoplastic. Polyethylene terephthalate occurs in groundwater, drinking water, soils and sediments. Plastic uptake by humans induces diseases such as reducing migration and proliferation of human mesenchymal stem cells of bone marrow and endothelial progenitor cells. Polyethylene terephthalate can be degraded by physical, chemical and biological methods.
\end{abstract}

Keywords PET $\cdot$ Persistence $\cdot$ Ecotoxicology $\cdot$ Biodegradation $\cdot$ Analysis

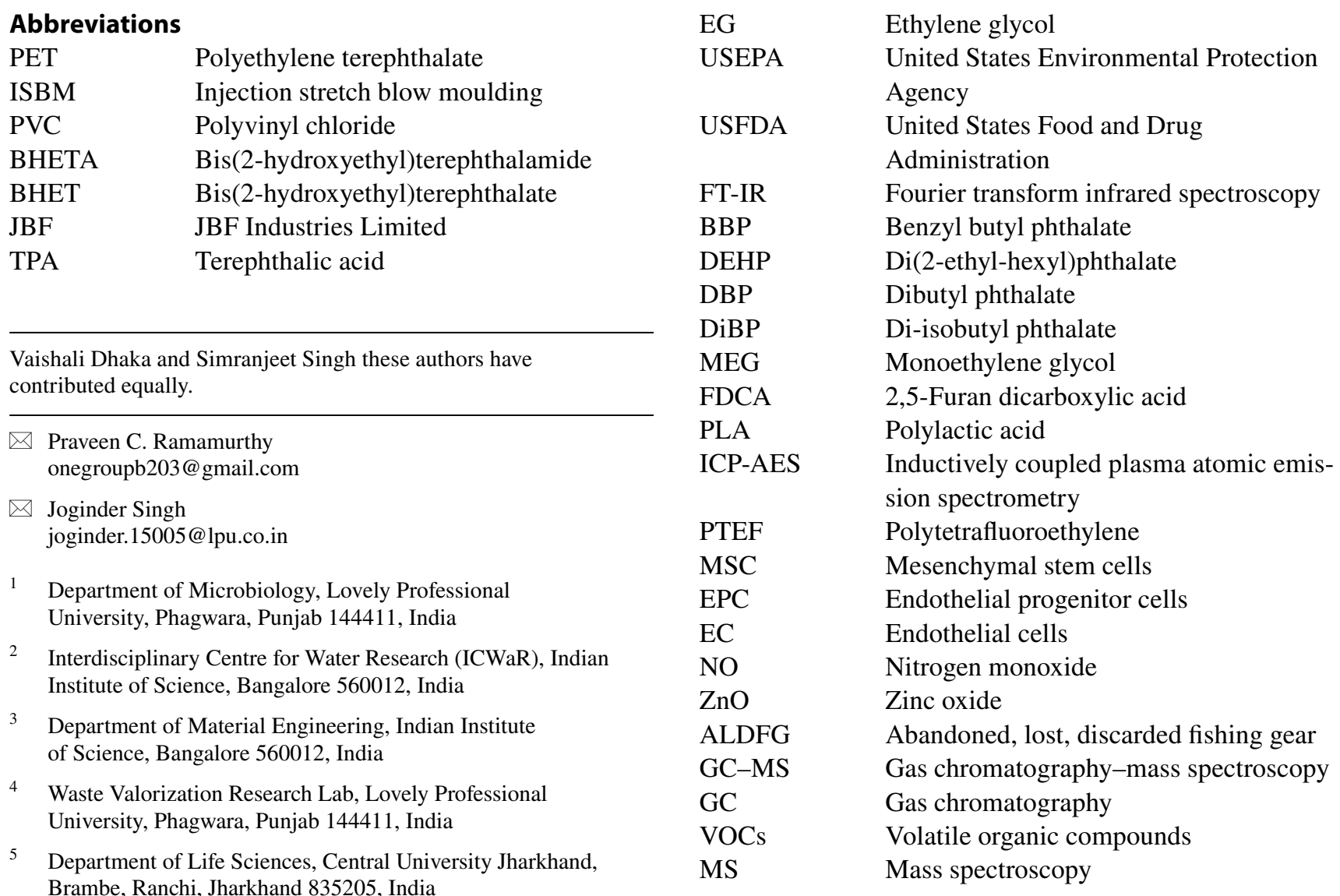




\begin{tabular}{|c|c|}
\hline TED GC-MS, & $\begin{array}{l}\text { Thermal extraction desorption gas chro- } \\
\text { matography-mass spectroscopy }\end{array}$ \\
\hline$\mu-\mathrm{GC}$ & Micro-gas chromatography \\
\hline SEM, & Scanning electron microscope \\
\hline DSC & Differential scanning calorimetry \\
\hline PEF & Polyethylene furanoate \\
\hline FTIR-ATR, & $\begin{array}{l}\text { Fourier transform infrared spectroscopy- } \\
\text { attenuated total reflectance }\end{array}$ \\
\hline UV & Ultraviolet \\
\hline FT-NIR & $\begin{array}{l}\text { Fourier transform near-infrared } \\
\text { spectroscopy }\end{array}$ \\
\hline EM & Electromagnetic \\
\hline IR & Infrared \\
\hline NIR, & Near infrared \\
\hline HPLC & High-performance liquid chromatography \\
\hline MHET & Mono-2-hydroxyethyl terephthalate \\
\hline RP-HPLC & $\begin{array}{l}\text { Reversed-phase high-performance liquid } \\
\text { chromatography }\end{array}$ \\
\hline SEC & Size exclusion chromatography \\
\hline PS & Polystyrene \\
\hline TGA-MS & $\begin{array}{l}\text { Thermogravimetric analysis mass } \\
\text { spectroscopy }\end{array}$ \\
\hline SMA & Stone mastic asphalt \\
\hline MTMS & Methyltrimethoxysilane \\
\hline rPET & Recycled polyethylene terephthalate \\
\hline$-\mathrm{OH}$ & Hydroxyl group \\
\hline $\mathrm{C}-\mathrm{H}$ Bond & Carbon-hydrogen bond \\
\hline$-\mathrm{COOH}$ & Carboxylic acid \\
\hline$-\mathrm{NH}_{2}$ & Amine group \\
\hline
\end{tabular}

\section{Introduction}

Polyethylene terephthalate (PET) is a linear thermoplastic polymer composed of the repeating units of terephthalic acid and ethylene glycol monomers (Yoshida et al. 2016). PET, polyurethane, polystyrene ( $<10 \%$ each), polyethylene $(36 \%)$, polypropylene $(21 \%)$ and polyvinyl chloride $(12 \%)$ are involved in the production of non-fibre plastics. The production of non-fibre products requires polyester, including $70 \%$ of PET (Geyer et al. 2017). PET is used in daily life, and it has many applications in different types of industries. It is extensively used in the industries of plastic films and fibres. The reason could be attributed to its high melting point and excellent mechanical properties (Ma et al. 2019). A composite fibre produced from PET with dry aerogel particles is used in the textile and automotive industries. The composite fibre materials are also utilized in water filtration and air purification systems (Christiansen et al. 2019). Since this polymer possesses versatile properties such as lightweight, gas barriers, high tensile strength and transparency, it is used to synthesize thin-walled containers. It is widely used as a packaging material in the food and beverage industries.
It is also used as an additive in the asphalt mixture (Zair et al. 2021). Plastic bottle wastes have also been used as an additive in road pavement projects to enhance the mixture of stone mastic asphalt. It showed a positive effect on properties o stone mastic asphalt, such as mixture stiffness and resistance against rutting (Ahmadinia et al. 2012).

A deformation process known as injection stretch blow moulding (ISBM) is used in framing different types of plastic bottles, jars, and containers at various rates of blowing and temperature (Nixon et al. 2017). Apart from plastics, this polymer is also used in making different types of detectors. For example, a gold electrode made with PET is used for sensing the glucose level in sweat and commercial beverages by a chemical plating technique via ultraviolet (Wang et al. 2019a).

PET is significantly used in the medical domain too. The demand for PET-based materials that are stable and durable for antimicrobial property coatings increases due to the spike in nosocomial infections and novel drug resisting bacteria in the current scenario. A terpolymer was coated with PET fabrics for the utilization of PET in several types of medical equipment. The terpolymer was synthesized using the dry pad cure procedure to inactivate Escherichia coli $\mathrm{O} 157: \mathrm{H7}$ and Staphylococcus aureus (Cerkez et al. 2016).

PET can be used as a plasticizer for the production of other products. The polymeric plasticizer is synthesized from the PET plastic waste to further produce nitrile rubber and rubber sheets of nitrile-PVC through alcoholysis depolymerization. The polymeric plasticizer enhances its mechanical properties (Sirohi et al. 2019). The fatty acid of jatropha oil amide and resorcinol has been used for the production of polyetherimide resin. The addition of bis(2hydroxyethyl) terephthalate results in modification of this resin. The other coating has been prepared using melamine-formaldehyde and improved by adding polyaniline at different concentrations. Three weight percent showed the best anticorrosive properties among the others (Rane et al. 2018). The fibres have a significant impact on the mechanical nature of all the substrates. The yarns of multifilament polyester have been produced with different extensibility values and converted into the same density of aerial fabrics. The bending rigidity is inversely proportional to the extensibility of the residual. The fabric sample having the extensibility of $18.75 \%$ of residual has a total value of 4.54 maximum, suitable for a thin application of ladies' dresses (Singh and Behera 2018).

Approximately 6300 metric tons of plastic waste had been produced, in which the terrestrial environment acquired $79 \%$ till 2015. By 2050, around 12,000 metric tons of plastic waste in landfills will be produced if the plastic's current production continues (Geyer et al. 2017). The most common municipal solid waste in PET plastic is a beverage and potable water bottles (Nanda and Berruti 2021b). In India, 
polyethylene terephthalate demand is growing due to the increasing population and urbanization. Hence, its consumption will be doubled during the year 2017-21. The bulk production of PET (around 60\%) is for synthetic fibres, and the remaining $40 \%$ is for plastic bottles. During 2016-2021, the compound annual growth rate of PET will achieve 21.93 metric tons. The demand will grow for the next five years due to this polymer's use in food, beverages and polyester industries.

According to the Markets report, the market growth rate during the forecast period of amorphous PET in terms of value will grow to the highest compound annual growth rate. The major countries contributing to the demand for amorphous PET are the Asia Pacific region countries, namely India, China, Australia and South Korea. The amorphous PET market is estimated to grow due to increased utilization of plastic bottles because most amorphous PET is used to manufacture plastic bottles. However, according to the life cycle assessment report, only $42 \%$ of PET bottles are recycled, and the remaining 38\% and 20\% are ended up in the landfill and burnt, respectively (Central Pollution Control Board 2018).

\section{Composition and types}

PET is made up of terephthalic acid and ethylene glycol and belongs to a high-molecular-weight thermoplastic, semicrystalline polymer (Webb et al. 2013). The short chain of aliphatic molecules, coupled with an aromatic ring, causes the polymer to become a stiff molecule. Therefore, it is used in industries, e.g. food, pharmaceuticals and textile industries. For example, it is employed as a food packaging material or a container to store different beverages in food industries. In contrast, in textile industries, it is used as polyester fabrics such as curtains, upholstery and wearing apparel (Venkatachalam et al. 2012). It is also used to make photographic films, X-ray and electrical insulations (Nanda and Berruti, 2021a). The composition of PET makes it a suitable candidate for multiple applications leading to an increase in demand. During PET manufacturing, low molecular weight oligomers $(<1000 \mathrm{Da})$ can be formed as side products of incomplete polymerization. The impurities present in raw materials used for the production of the packaging material can also result in the formation of oligomers (Mohd Ishak et al. 2006). The oligomers can also be produced by sunlight degradation or by interacting with beverages and food contact such as hydrolysis (Muncke et al. 2017; Koster et al. 2015; Nerin et al. 2013). These are considered as nonintentionally added substances as described in Commission Regulation (EU) No 10/2011. They may migrate from packaging into food products (Begley et al. 1990; European Union 2011).

\section{Properties}

The poly(ethylbenzene-1,4-dicarboxylate) is the IUPAC (The International Union of Pure and Applied Chemistry) name of PET polymer, and its resin identification code or recycling number is 1 (Nanda and Berruti 2021a).The density of PET is $1.38 \mathrm{~g} / \mathrm{cm}^{3}$, which is higher than water because it sinks in the water. The degree of crystallinity affects the PET optical properties. Opaque PET is semicrystalline, whereas transparent PET is amorphous. This transparency loss in polymeric materials of crystalline is given by forming the crystalline spherulites, which scatter light (Jabarin 1982). The main chain of PET constitutes polar groups and aromatic rings, favouring an improved stiffness and thermal stability of the polymer. The melting point $\left(T_{m}\right)$ of semi-crystalline PET is $255-265{ }^{\circ} \mathrm{C}$ which is high for a polymer. The glass transition temperature $\left(T_{g}\right)$ of amorphous and semi-crystalline PET is $67^{\circ} \mathrm{C}$ and $80^{\circ} \mathrm{C}$, respectively, whereas $T_{g}$ is raised to $125^{\circ} \mathrm{C}$ in oriented chains and crystalline PET (Lepoittevin and Roger 2011; Morris 2016).

Moreover, the temperature above $T_{g}$ PET is sensitive to hydrolysis (Wang and Wang 2004). It is chemically inert towards several reactants and solvents, but it is sensible towards hydrocarbons, strong bases and acids, and weak bases. It is soluble in hexafluoroisopropanol, trifluoroacetic acid and ortho-chlorophenol (Lepoittevin and Roger 2011). $T_{g}$ of polyethylene terephthalate is very important property to understand the aging of PET which is also related to degradation of the polymer as it may lead to stiffness and generation of microplastics and nanoplastics with time.

\section{Food packaging industry}

Traditionally glass bottles are preferred to be stored in carbonated beverages, but nowadays, PET bottles are favoured, as glass bottles are brittle, heavy and breakable. The industrial market prefers PET bottles for carbonated products due to their transparency, strength and durability (Alvarado Chacon et al. 2020). It is also used for the production of textiles (Sevigné-Itoiz et al. 2015; RomeroHernández et al. 2009). The company of Coca-Cola in 1969 performed the first study of life cycle assessment (LCA) of PET. Their study showed that PET bottles have less impact on the environment than their glass counterparts (Saleh 2016). It is also used in other markets to store fruit juices, sports drinks, salad oils, dressings and sauces. In the last 20 years, the resin market of packaging has been observed strong growth. They are virtually unbreakable, 
and around 40-45 $\mathrm{g}$ of $1.5 \mathrm{~L}$ PET bottle weighs about onetenth the glass bottle weight ( $\mathrm{Li}-\mathrm{Na} 2013$ ). The PET plastic film is also used as an oxygen barrier in food packaging (Gaikwad et al. 2018). For packaging the fresh meat as well as fresh produce, a wide range of PET trays are used. Most of the antifogging polymeric films are also made up of PET used in food packaging applications (Gaikwad et al. 2019; 2020). The demand for PET in the food industry is not going to diminish until a suitable alternative will fill it. So, the understanding and mitigation of PET are very essential.

\section{Polyethylene terephthalate in the environment}

\section{Groundwater and drinking water}

The drinking water or groundwater is getting contaminated with PET plastic or the products leached from the PET plastic. Some studies have described the migration of microplastic from PET plastic into the water. The military water packaged in PET was tested and observed for $\mathrm{pH}$ values and odour intensity. These were found to increase after long-term storage of water compared to the limits provided by the United States Environmental Protection Agency (USEPA) and the United States Food and Drug Administration (USFDA) (Greifenstein et al. 2013). Current studies showed microplastics using FT-IR spectroscopy from bottled water, tap water and drinking water from ground sources. Of the sourced faucet water from one hundred fifty-nine samples, eight one per cent were found consisting of microplastic particles smaller than five millimetres with a mean of 5.45 particles/L (Kosuth et al. 2018). From an aggregate of two hundred fifty-nine individual's bottle water, ninetythree per cent exhibited microplastic with a normal of 10.4 particles/L (Mason et al. 2018). From the north-western part of Germany, groundwater analysis revealed an overall mean of0.7 particles of microplastics $/ \mathrm{m}^{3}$ (Mintenig et al. 2019). The impact of capacity, time and temperature was studied on antimony $(\mathrm{Sb})$ migration from PET containers into mineral water in three different coloured bottles: dark blue, light blue and clear for short (15 days) and long durations (220 days). The studies demonstrated that water stored at 4 and $20{ }^{\circ} \mathrm{C}$ was not exposed to antimony relocation.

In contrast, at $40{ }^{\circ} \mathrm{C}$ temperature, a noteworthy increment in the concentration of $\mathrm{Sb}$ was observed. However, the maximum limit of $5 \mu \mathrm{g} / \mathrm{L}$ provided by the European Union was not surpassed. The antimony migration was seen in the samples stored at $60{ }^{\circ} \mathrm{C}$ for 30 days and was above the permissible limits of the European Food Safety Authority (EFSA) of antimony with oxidation states +3 and +5 (Carneado et al. 2015; Anadón et al. 2011). This report screened 38 non-carbonated samples from which more than half of the samples in the clear container show lower amounts of $\mathrm{Sb}$ than those put away in coloured containers. It contains total antimony between 191 and $268 \mathrm{mg} / \mathrm{kg}$. This shows that microplastics could be potential carriers of heavy metals to various regions like mountains, rivers, and forests through water, air and land. This may lead to heavy metal pollution in areas that are not connected to the source which is a matter of great concern.

Degradation due to sunlight exposure of three different kinds of PET bottles containing carbonated water in green and pink-coloured, drinking water in the clear bottle for eight months was examined (Chaisupakitsin et al. 2019). It was found that the tensile strength decreases, but the plastic's shape remained unchanged. However, the fusion enthalpy, which corresponds to the rearrangement of molecules in plastic, increases. FTIR data revealed the light increment in the hydroxyl group's peak on the bottle's outer surface due to the reaction of photo hydrolysis. Along with the chemical structural changes, the $\mathrm{pH}$ of liquid also changes from acidic to basic. The reason could be attributed to the pigments present in coloured bottles. The presence of aldehyde was only observed in clear bottle drinking water. It was also seen that the anionic concentrations of fluoride, chloride, nitrate ion and sulphate decreased in the drinking and increased in water stored in the green-coloured bottle during sunlight exposure of time as it accelerates the reactions of fluorination and chlorination. However, the anion concentration of the water stored in the pink-coloured bottle did not change compared to others. It was also revealed that sunlight has critical consequences for relocating acetaldehyde and aldehyde into drinking water. They were not found in the sample of carbonated water, but their turbidity rises. The release of contents from plastic during weathering needs to be explored further to understand their impact on ecosystem.

The acetaldehyde, formaldehyde, 2,4-di-tert-butyl-phenol (2,4-dtBP) and bis(2-hydroxyethyl) terephthalate migrated into the water stored in the PET bottle. These compounds are released due to carbon dioxide and increased temperature (Bach et al. 2012). The polymer matrix of PET is characterized by a limited variety of additives (Anadón et al. 2011). However, non-intentionally added substances (NIAS) of non-polymer origins also exist in PET bottled waters. Therefore, bis(2-hydroxyethyl) terephthalate and 2,4-dtBP were identified as non-intentionally added substances (Bach et al. 2013). Cincotta et al. (2018) identified the aromatic and aliphatic hydrocarbons, unsaturated and saturated aliphatics such as phthalates, terpenes, ketones and aldehydes in PET bottled mineral water. The most abundant identified compounds were nonanal and decanal. These compounds were considered non-intentionally added substances, and their level increases statistically during the shelf life. 
The phthalates, namely benzyl butyl phthalate, bis(2-ethylhexyl) phthalate (DEHP), dibutyl phthalate and di-isobutyl phthalate, were found in water from recycled containers of PET with 20-30\% reused content (Keresztes et al. 2013). Whereas benzyl butyl phthalate, dibutyl phthalate and dibutyl phthalate were observed to be missing, the degrees of DEHP were firmly decreased in water tests from bottles made out of virgin PET. Levels of plasticizers released into the environment during weathering need more study to understand their impact on natural diversity and as well to understand the migration of plasticizers by PET.

\section{Marine waters}

All types of plastics eventually end up in the oceans, where they disintegrate into micro- or nano-plastics after some time. The microplastic and one of their plasticizers, di(2ethylhexyl) phthalate, become easily accessible for ingestion by various life forms. Indeed, microplastics and plasticizers represent a genuine danger to zooplankton and possibly higher trophic levels (Vered et al. 2019). Exposure to microplastic and plasticizers can result in severe long-term along with short-haul effects on Parvocalanus crassirostris survival, fertility, population and gene expression. The impact of prolonged micro-plastic exposure on population viability has severely deleterious effects (Heindler et al. 2017). Based on in-situ observation, $4.9 \times 10^{5}$ tons of floating microplastics was found in 2010 (Eriksen et al. 2014). Everaert et al. (2018) predicted that by the year 2100 , the microplastic floating mass would go up to $2.5 \times 10^{7}$ to $1.3 \times 10^{8}$ tons, directly a 50-fold increase in micro-plastic between 2010 and 2100. The idea of degrading plastic was once the most desired output, but now it is something to be avoided as the reduction in their size increases their surface area leading to migration of undesired pollutant adsorbing onto their surface. The increasing floating mass concentration of PET and other plastics are a serious threat as they mask the oxygen interaction surface on the water and may replace the floating biomass which is crucial for biogeochemical cycles. Further detailed research on such will provide a resolution about this.

\section{Soils}

Due to plastic waste's hazard disposal, the land is becoming infertile (CPCB 2015). The soil nutrients are getting depleted, due to which plant growth is restricting, and productivity decreases. The primary source of microplastic litter is plastic used for packaging purposes. It accounts for the maximum solid waste in landfills, which may degrade or remain unchanged for several years. Plastic may have negative effects on soil properties, such as decreased soil stability and water retention. It also blocks the porosity of the soil, which affects the evaporation rate (Qi et al. 2020a, b). Once microplastic mixes with soil matrix, they may alter the soil porosity, thus affecting soil water dynamics and soil aggregation. This may also lead to the change in the biodiversity in soil and the biomass quantity too. More research has to be done to better understand its impact.

Bioplastic such as 2,5-furan dicarboxylic acid (FDCA) can replace terephthalic acid. It does not negatively impact human health and the environment (Chen et al. 2016). However, at concentrations higher than the $30 \mathrm{mg} / \mathrm{kg}$ soil, terephthalic acid decreases the Folsomia candida efficiency for reproduction. Nonetheless, the terephthalic acid compound stays stable in sterile soil as it achieved a higher lethality level. Therefore, it was utilized as the structure hinder for plasticizers during PET production. However, it has been demonstrated to be harmful to the vertebrate's reproduction system (Ball et al. 2012). The impacts of plasticizers are still not studied much in the environmental matrix. Alternative bio-plastisizers should be explored which may prove to be better solution.

\section{Sediments}

Various factors are involved in distributing plastic in the bottom of the ocean, including recreational, shipping, fisheries and aquaculture activities. The coastal area of tourism, industrially polluted river outlets are the major factors to cause pollution in the sediments (Loulad et al. 2017). The areas with lower water circulation, such as channels and rifts, cause plastic litter in the sediment part. Macro-, micro- and meso-plastics were found in the sediments.

\section{Macroplastic}

The monitoring of the abundance of macroplastic litter has been done regularly in some countries. Although the abundance of litter remained constant from 1994 to 2014, minor litter quantity increased statistically in the Gulf of Lion, France (Galgani, 2019). During the international bottom trawl survey, no variation was found over 25 years in the form of percentage and plastic debris weight (Maes et al. 2018). From 2007 to 2016, no data were found on the abundance of macroplastic litter in China (GESAMP 2019).

In 8 years, the profusion of macroplastic litter increased near Greece's areas (Koutsodendris et al. 2008). For example, at the Observatory of Hausgarten (Fram Strait), the plastic waste increased at a depth of 2,500 $\mathrm{m}$ in the deep sea between 2003 and 2016 (Tekman et al. 2017). With increasing demand for plastics during COVID-19, for packed foods, hospital kits and masks, the increase in disposing microplastic has inevitably increased in land and water. Proper plastic management strategies are required to reduce the litter. 


\section{Mesoplastic}

The small particles of mesoplastic of size $0.5-8 \mathrm{~mm}$ were found in the sediment area of two beaches, namely Kahuku and Kamilo beach, located on the Hawaii Island (Young and Elliott, 2016). In India, different sediment samples of the river Ganga from different locations such as Fraserganj, Bhagalpur, Godakhali, Buxar, Nabadwip, Patna and Barrackpore were collected to observe the abundance of mesoplastic. All the sediments were polluted with a greater than $5 \mathrm{~mm}$ mesoplastic size, and majorly PET mesoplastic was found in the Ganga River (Sarkar et al. 2019). The samples were collected from the Adriatic Sea (Croatian marine) sediments to analyse the mesoplastic litter distribution. A total of $11.29 \%$ mesoplastic was found in the sediment sample (Blašković et al. 2017). The presence of mesoplastic is an indicator for further degradation of plastic into micro- and nanoplastic particles.

\section{Microplastic}

The particles of polycyclic aromatic hydrocarbons microplastic $(<5 \mathrm{~mm})$ are deposited in the deep oceans. They are so ubiquitous that their presence is found in all marine environments (Yu et al. 2018; Besley et al. 2017). The size equal to or less than $100 \mathrm{~nm}$ of microplastic subfraction in at least one dimension is known as nanoplastics (Ekvall et al. 2019). Around 4300 microplastics per kg (dry sediment) was recorded as the peak concentration of microplastic litter in Tasmania (Willis et al. 2017). Dodson et al. (2020) found nylon, polypropylene, polyethylene, PET and polystyrene microplastics in the beach sediments from the states of USA, namely North Carolina and Virginia. Pyrolysis-gas chromatography-mass spectroscopy techniques were used to detect the presence of these microplastics. Microplastics' presence was also detected in the sediments of Suva's urban coastal environment, the capital of Fiji. It was found that the sewage treatment plant was the main contributor to the increased microplastic levels in sediments (Ferreira et al. 2020). Zhang et al. (2019) observed the microplastics particles in the offshore sediments in the Sea of East China and the Yellow Sea, China. They found that $89 \%$ of microplastics was lesser than $1000 \mu \mathrm{m}$ in size. The microplastics identified in the offshore sediment area were PET, polyester, cellophane, polyethylene, and cellulose. The pieces of PET microplastics were also found in the sediment region of Lake Huron of Canada, along with polyethylene and polypropylene plastic (Zbyszewski and Corcoran 2011). The lakes present in the remote area of Tibet Plateau, China, were also found contaminated with the PET microplastics in the sediment zone (Zhang et al. 2015). Horton et al. (2017) reported that the dominant polymer found in the sediments of the Thames River, UK, was polyester or PET and polypropylene. The presence of PET in sediment indicates that they may interact with sediment microbes and organisms too. Their effect on the living organism in sediment depends on their plasticizer and temperature.

\section{Nanoplastics}

Nanoplastics (NPs) mainly originate from the transformation and fragmentation of larger plastic particles and are less than $100 \mathrm{~nm}$ in size (Galgani 2019). Due to natural forces such as biological metabolism, ultraviolet radiation and mechanical forces of water, the shapes of resulting nanoplastics become hardly spherical and smooth. However, data on the migration of nanoplastics in aquatic ecosystems are poorly investigated. Hence, findings from microplastics may provide some insights into this field. Different models have been proposed to predict the migration of nanoplastics in aquatic ecosystems considering the vastness of oceans. Both empirical and theoretical models indicate that the currents of oceans redistribute the particles of plastic in surface oceanic waters, which will accumulate in five major "garbage patches" located in the Indian Ocean, South and North of Atlantic, and South and North of Pacific Ocean (Hale et al. 2020; Mountford and Morales Maqueda 2019). The nanoplastic mitigation has to be done by preventing the entry of plastics into environment; reuse of plastic is one of the important reasons for presence of micro- and nanoplastic in the environment.

\section{Toxicity}

\section{Exposure to humans}

Nanosized particles of PET plastic have raised severe concern regarding potential dangers and risks of nature and human well-being. Exposure of nanoplastic to human beings may happen through oral inward breath, ingestion, or assimilation by the skin regarding plastic items' utilization (Prata 2018). The ingestion of plastic nanoparticles will probably be the primary entry route since these particles can be consumed by eating fish or drinking polluted water. On the other hand, plastic uptake in humans may happen by volitional swallowing, leading to the worst scenario: gastrointestinal obstruction, mental sicknesses, asthma, allergy, and chronic pneumonia (Yaka et al. 2015). Microplastics consist of additives and monomers, reported as endocrine disrupters (Vethaak and Leslie 2016; Othman et al. 2021). According to the report, PET particle size ranged from 50 to $500 \mu \mathrm{m}$ was found in the stool sample of humans (Schwabl et al. 2019). The toxicity of PET in humans is represented in Fig. 1. 


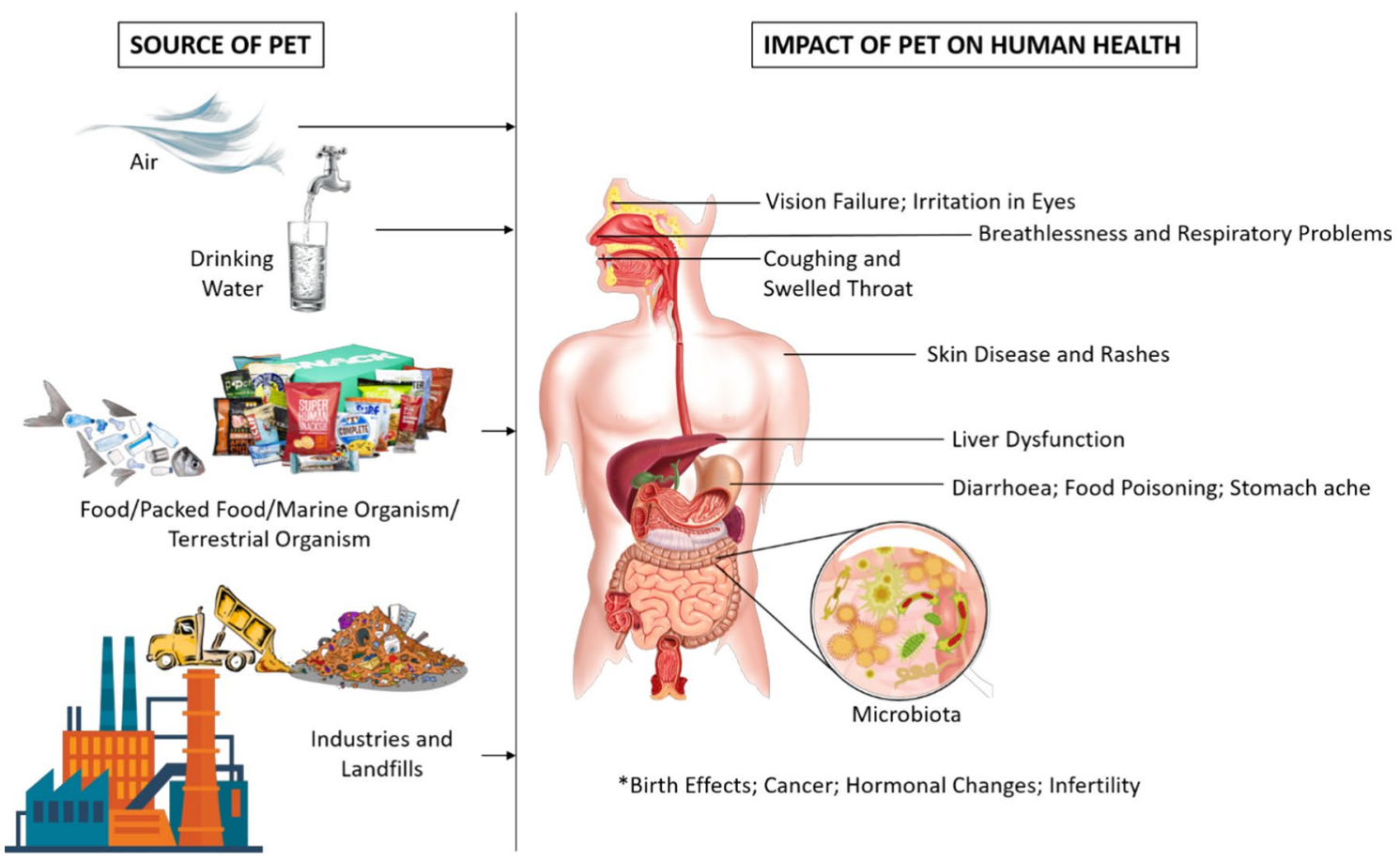

Fig. 1 Potential sources of polyethylene terephthalate in air, land, water and its associated negative health hazards on various human organs

The antimony goes as a conceivable cancer-causing agent in the human body; it is radiated from the compartment for extensive stretches of contact with drinking water. Suppose water is in contact with the PET plastic for a longer time. The probability of antimony discharge increases, leading to dermatitis, irritation in the respiratory tract, changes in electrocardiograms, and gastritis in humans. Recycled PET contains catalysts of heavy metal; the most common is antimony used to manufacture packaging material for food. The food is coming into direct contact with the container (Whitt et al. 2016). The stability of recycled plastic is lesser than the virgin proving to be a vital source for pollution.

The impact of PET and polytetrafluoroethylene (PTFE) vascular prostheses was analysed to expand, relocate and produce NO in various human cells. The mesenchymal stem cells of bone marrow, human endothelial progenitor cells and EA hy926 endothelial cells were used to study its impact on human health. They have also analysed colonization of the prosthesis surface by endothelial and mesenchymal cells (Lykov et al. 2019). It was observed that in the presence of PET, proliferation and migration of these cells were suppressed. However, it enhances the production of nitric oxide by endothelial progenitor cells and mesenchymal stem cells only. PET has also reduced the migration and proliferation of these cells. Therefore, toxic effects are produced on mesenchymal and endothelial cells. Different types of PET plastic have to be studied and compared to understand, whether it is the size or the plasticizer which exhibits toxicity.

\section{Other organisms}

Microplastics were exposed to the earthbound snails for 28 days to assess their toxic effects on the snail Achatina fulica. Prolonged exposure of PET microplastic fibres to forty snails exhibits a reduction in food and excretion intake around $24.7-34.9 \%$ and $46.6-69.7 \%$, respectively. Moreover, it also induces villi damage in the gastrointestinal walls and decreases glutathione peroxidase level up to $59.3 \pm 13.8 \%$ (Song et al. 2019). Therefore, the microplastic affects the soil life forms and disturbs the balance between the antioxidant responses and reactive oxygen species present in the soil environment. Furthermore, Zhang et al. (2010) demonstrated that the quantities of viable spermatogenic cells decreased in male mice in the presence of terephthalic acid wastewater, showing conceptive lethality.

Accumulation of nanoplastic in fish has also been reported by Crossman et al. (2020) in which the nanoplastic affects the shoaling behaviour and feeding activities of fishes. Increased concentrations of nanoplastics lead to the disruption of the metabolic processes by enhancing the concentration of ethanol, lysine and adenosine in the liver of the fishes (Crossman 2020).

Bhargava et al. in 2018 have assessed the aggregations of nanoplastics inside the body of the barnacles (marine crustacean) by conducting toxicity tests. Results indicate that continuous exposure leads to the alteration of the signal molecules resulting in the interference of lipid metabolism. 
Dong et al. (2018) reported that the simultaneous exposure of $\mathrm{TiO}_{2}$ nanoparticles and polystyrene on nematodes results in the generation of the oxidative stress which directly affects the locomotory conduct of the species. Effect of plastic particles on Mytilus galloprovincialis results in the reduction in their enzyme actions, damage to lipid peroxidation system and stimulation of neurotransmission (Brandts et al. 2018). In addition to this, embryonic abnormalities and growth rate inhibition after being exposed to PET nanoplastics have been observed (Brandts et al. 2018; Song et al. 2019; Othman et al. 2021). Various evidences depict the harmful effects of PET and its metabolites on different organisms by disrupting the endocrine and estrogenic hormones. Few studies have been reported till date which represents the effect of PET on the reproduction rate of the organisms.

\section{Remediation}

For reducing the PET plastic from the environment, various physical and chemical methods are used. It involves incineration, pyrolysis, photodegradation, alcoholysis, acid hydrolysis, and ammonolysis. Their advantages and limitations are explained in Table 1. These processes are easy to perform, and no additional sources are required to carry out. However, these methods have more demerits as compared to their merits. The released toxic compounds and their byproducts are harmful to the environment in many ways and affecting living organisms. Therefore, PET plastic's biological treatment with bacteria and fungi is the most suitable and sustainable approach to managing plastic waste to reduce this issue. Although it is a time-consuming process, it is observed that it has negligible effects on the environment.

\section{Recycling}

According to international standards of life cycle assessment, closed-loop and open-loop methods are the two different recycling processes (Gomes et al. 2019). The former occurs if the same product is produced using the same process of reintroducing the material. In contrast, the latter occurs when another process is used to manufacture a different product, for example, insulation material or fibre (Ingrao et al. 2014, 2016; Van Der Velden et al. 2014; Intini and Kühtz 2011; Williams et al. 2010; Shen et al. 2010). The bottle-to-bottle close-loop recycling means when the productive cycle end product return to bottles from PET bottles (Chilton et al. 2010). However, the open-loop recycling process offers many ways to produce the new material, comprising back to monomer, back to the oligomer, semimechanical and mechanical recycling (Shen et al. 2010). PET bottle post-consumer treatment's associated impacts include incineration, thermal, landfill disposal, chemical and mechanical recycling (Komly et al. 2012). Generally, PET bottle recycling significantly reduces global warming, greenhouse gas emissions, fossil resource consumption compared to landfills, incineration and chemical recycling (Kuczenski and Geyer 2013; Foolmaun and Ramjeeawon 2013; Nakatani et al. 2010).

The EFSA evaluated the risks of recycling processes and managed them by an appropriate quality assurance system (Barthélémy et al. 2014). Welle (2016) determined the crosscontamination amount during the recycling process of PET between noncontaminated and contaminated flakes. It was found at a 1:1 mixing ratio, especially methyl stearate and benzophenone low volatile surrogates, whereas chlorobenzene, methyl salicylate, chloroform and phenyl cyclohexane volatile surrogates do not show cross-contamination (Welle et al. 2016). Recycling of PET is still an uncertain solution

Table 1 Methods to treat polyethylene terephthalate waste with their advantages and limitations

\begin{tabular}{|c|c|c|c|c|}
\hline Treatment & Methods & Advantages & Disadvantages & References \\
\hline Physical & $\begin{array}{l}\text { Incineration } \\
\text { Pyrolysis } \\
\text { Thermal degradation } \\
\text { Photodegradation }\end{array}$ & Cheap, process is simple & $\begin{array}{l}\text { Releases harmful gases and toxic } \\
\text { products }\end{array}$ & $\begin{array}{l}\text { Dhahak et al. (2019); Dimitrov } \\
\text { et al. (2013); Brems et al. } \\
\text { (2011b,a); Lian et al. (2011); } \\
\text { Ganeshan et al. (2018); Gewert } \\
\text { et al. (2015); Das and Tiwari } \\
\text { (2019) }\end{array}$ \\
\hline Chemical & $\begin{array}{l}\text { Hydrolytic degradation } \\
\text { Glycolysis } \\
\text { Alcoholysis } \\
\text { Acid hydrolysis } \\
\text { Ammonolysis } \\
\text { Aminolysis }\end{array}$ & $\begin{array}{l}\text { Requires no additional source } \\
\text { Requires mild reaction }\end{array}$ & $\begin{array}{l}\text { Require high temperature } \\
\text { High-cost chemicals } \\
\text { Unsaturated and polyester resins } \\
\text { are formed } \\
\text { Oligomeric plasticizers } \\
\text { Catalyst residues, dyes and addi- } \\
\text { tives contaminants present }\end{array}$ & $\begin{array}{l}\text { Arhant et al. (2019); Raheem et al. } \\
\text { (2019); Raheem et al. (2018); } \\
\text { Zhou et al. (2019); Sinha et al. } \\
\text { (2010); Wakabayashi et al. } \\
\text { (2012); Viana et al. (2011); } \\
\text { Wang et al. (2019b) }\end{array}$ \\
\hline Biological & Microbial biodegradation & $\begin{array}{l}\text { No harmful gases and products } \\
\text { Eco-friendly } \\
\text { Natural process }\end{array}$ & Time-consuming & $\begin{array}{l}\text { Goel et al. (2014); Farzi et al. } \\
\text { (2019); Vague et al. (2019); } \\
\text { Yoshida et al. (2016) }\end{array}$ \\
\hline
\end{tabular}


as the wear and tear of recycled PET as well as the weathering rate of it in environment may be more. Understanding it is more important to avoid the scenario of providing a solution which leads to new problems which has been happening in many cases, of which introduction of plastic to packing industry is the appropriate example.

\section{Role of nanocatalysts}

The breakdown of PET polymers requires extensive catalysts. Zinc oxide $(\mathrm{ZnO})$ nanocatalysts of different particle sizes and weight ratios were used for the chemical recycling of waste PET bottles $(3 \times 3 \mathrm{~mm})$ (Alzuhairi et al. 2017). Bis(2-hydroxyethyl) terephthalate was the main product found after PET degradation using the nanocatalystperkalite F100 (Guo et al. 2018). Rezende et al. (2019) synthesized the nickel catalyst, thus achieving a $97 \%$ degree of conversion. $\mathrm{Fe}_{3} \mathrm{O}_{4}$ nanoparticle was immobilized on boron nitride nanosheets to recycle PET wastes by glycolysis (Nabid et al. 2019). Sodium or protonated titanate nanotubes were used for the post-consumer and virgin PET degradation (Lima et al. 2019). Still the effect of such nanomaterial to the dynamic environment condition and their stability have to be explored in detail. More research on such activity is required understand the reaction PET with nanomaterials and their long-term impact.

\section{Biological treatment}

The monomer of PET becomes a substrate for Pseudomonas putida by enzymatical degradation (Wierckx et al. 2015). Delftia species WL-3 (Liu et al. 2018a) degrades the PET and its constituent, i.e. dimethyl terephthalate (DET), approximately $94 \%, 5 \mathrm{~g} / \mathrm{L}$, and uses it for growth as the sole carbon source within seven days. Acero et al. (2011) demonstrated that endo-type scission is involved in the cleavage of internal ester bonds during the hydrolysis of PET. Farzi et al. (2019) depolymerized the PET by Streptomyces species. The percentage of biodegradation rate for $212 \mu, 300 \mu, 420 \mu$ and $500 \mu$ sizes of PET particles were 68.8, 62.4, 57.4, 49.2\%, respectively. The Aeromonas strain was used as a biocatalyst to depolymerize and assimilate the PET using a whole-cell bioprocess technique (Gong et al. 2018b).

Vague et al. (2019) isolated the microbial species from the polluted petroleum sites in Houston, Texas, for the effective degradation of PET. Some of the samples were pre-treated by ultra violet radiation which enhanced plastic degradation. They have formed the consortium of the five different bacterial species, i.e. three Pseudomonas species and two Bacillus cereus, enhancing the degradation process. In the compost soil, biodegradation of PET using rhizosphere microorganisms was performed. The bacterial strains, namely Serratia plymuthica IV 111-34 and Arthrobacter sulfonivorans III
111-20, were isolated from the rhizospheric region of the Salix viminalis plant (Janczak et al. 2018). Two mycorrhizal fungi strains have also been isolated along with the bacterial strains, namely Laccarialaccata and Clitocybe sp. IV 116-1a to degrade this polymer. An approximate 15 to $35 \%$ drop in the polymer's strength was observed (Janczak et al. 2018). Many enzymes produced by bacteria and fungi (Table 2 ) are reported to degrade PET. Enzymes such as esterase hydrolyse ester bonds to amino acids and alcohols present in PET polymer. Also, the lipase enzyme cleaves the esters, which are water-soluble or $\mathrm{OH}$ group esters. PETase and MHETase enzymes are responsible for PET and mono-2-hydroxyethylterephthalate polymer breakdown into their co-monomers, respectively (Kawai et al. 2014; Yoshida et al. 2016; Carniel et al. 2017). PETase enzyme involves PET degradation (represented in Fig. 2), and its mechanism is explained in Table 3. Yoshida et al. (2016) isolated Ideonella sakaiensis 201-F6 bacteria for the biodegradation of PET from the recycling site of the PET bottle. This bacterium adheres to the surface of PET and releases the PETase enzyme to target the polymer. Further, it produces the MHETase enzyme, which converts the intermediate product mono-2-hydroxyethylterephthalate into terephthalic acid and ethylene glycol formed after the breakdown of PET. Till now, the highest degradation of PET, i.e. $75 \%$ and $68.8 \%$, was reported by Yoshida et al. (2016) and Farzi et al. (2019) using Ideonella sakaiensis and Streptomyces species of bacterium, whereas, in fungi, Trichoderma species have been found to degrade 7\% of PET (Chaves et al. 2018). Microorganisms have maintained the biogeochemical balance of the earth since the beginning. So, exploring their role in mitigating the PET pollution is the right step. But further in-depth understanding involving interdisciplinary research supported by right funding would assist in understanding natural solution and also to create enzyme-based products for PET mitigation.

\section{Sample collection, process and characterization in the environment}

Strategies employed for the collection of macro plastics from the oceans depend on several factors such as identification of accumulation hotspots, the presence of specific litter even after the implementation of preventative measures, the management and distribution of abandoned, lost or otherwise discarded fishing gear and the influence of discharged waste coming from rivers. The sampling methods vary with the compartment under analysis, like surface water or water column and the litter's size distribution in the water (GESAMP 2019). For the separation of microplastic from surface water, the main sampling tool is manta trawls, whereas spatula, scoop, trowel and shovel are the most frequently used sampling tools for microplastic separation from 
Table 2 Bacterial and fungal genes and enzymes involved in the biodegradation of polyethylene terephthalate

\begin{tabular}{|c|c|c|c|}
\hline Bacteria & Gene, enzymes or attacking bond & Degradation $\%$ & References \\
\hline Acinetobacter baumannii & $\mathrm{C}-\mathrm{H}$ bond & $27.363 \%$ & Hussein et al. (2018) \\
\hline Ideonella sakaiensis & $\begin{array}{l}\text { PETase, MHETase, TPA dioxy- } \\
\text { genase and PCA dioxygenase } \\
\text { enzymes }\end{array}$ & $75 \%$ & Yoshida et al. (2016) \\
\hline $\begin{array}{l}\text { Thermobifida cellulosilytica } \\
\text { Thermobifida fusca }\end{array}$ & $\begin{array}{l}\text { Thc_Cut1 and The Cut2 } \\
\text { Thf } 42 \_C u t 1\end{array}$ & - & Herrero Acero et al. (2011) \\
\hline Thermobifida fusca KW3 & TfCut 2 & $20.4 \%$ & Barth et al. (2016) \\
\hline Thermobifida alba AHK 119 & est119 & - & $\begin{array}{l}\text { Hu et al. (2010); Thumarat et al. } \\
\text { (2012) }\end{array}$ \\
\hline Thermobifida alba & Tha_Cut1 & - & Ribitsch et al. (2012a) \\
\hline $\begin{array}{l}\text { Saccharomonos poraviridis } \\
\text { AHK190 }\end{array}$ & Cut190 gene /Cutinase enzyme & $\begin{array}{l}\text { 13.5\% (PET-GF) and 27\% (PET- } \\
\text { S) }\end{array}$ & Kawai et al. (2014) \\
\hline Nocardia species & Esterase enzyme & $8 \%$ & Sharon and Sharon (2013) \\
\hline Comamonas testosterone $\mathrm{F} 4$ & - & $\begin{array}{l}1.81 \% \\
\text { (Crystallinity increases) }\end{array}$ & Gong et al. (2018b) \\
\hline Streptomyces species & - & $68.8 \%$ & Farzi et al. (2019) \\
\hline $\begin{array}{l}\text { Bacillus subtilis } \\
\text { Bacillus halodurans } \\
\text { Bacillus okuhidensis } \\
\text { Bacillus pumilus }\end{array}$ & - & $\begin{array}{l}0.3 \% \\
0.2 \% \\
0.1 \% \\
0.4 \%\end{array}$ & Chaves et al. (2018) \\
\hline Thermobifida halotolerans & Thh_Est or Esterase enzyme & $\begin{array}{l}50.4^{\circ} \\
\text { (hydrophilicity increases) }\end{array}$ & Ribitsch et al. (2012b) \\
\hline Thermonosporacurvata & Tcur 1278 & - & Wei et al. (2014) \\
\hline Bacillus subtilis 168 & $\mathrm{SP}_{\text {PETase }}$ (Signal peptide) & - & Huang et al. (2018) \\
\hline $\begin{array}{l}\text { Consortium1: } \\
\text { Bacterium Te68R } \\
\text { Microbacterium species } \\
\text { Pseudomonas putida } \\
\text { Consortium CPII: } \\
\text { Pseudomonas otitidis }\end{array}$ & $\begin{array}{l}\mathrm{C}-\mathrm{H} \\
\mathrm{O}-\mathrm{H} \\
\mathrm{C}=\mathrm{O}\end{array}$ & $\begin{array}{l}95.91^{\circ} \mathrm{C} \text { and } 105.19^{\circ} \mathrm{C} \\
\left(\mathrm{T}_{\mathrm{g}} \text { decreases from } 107.76^{\circ} \mathrm{C}\right)\end{array}$ & Goel et al. (2014) \\
\hline $\begin{array}{l}\text { Pseudomonas putida } \\
\text { Pseudomonas chlororaphis } \\
\text { Bacillus cereus }\end{array}$ & Lipase enzyme & - & Vague et al. (2019) \\
\hline $\begin{array}{l}\text { Pseudomonas species } \\
\text { Bacillus thuringiensis } \\
\text { Bacillus albus } \\
\text { Bacillus aerius } \\
\text { Acanthopleuribacter pedis } \\
\text { Bacillus cereus }\end{array}$ & Lipase enzymes & - & León-Zayas et al. (2019) \\
\hline $\begin{array}{l}\text { Aspergillus species } \\
\text { Penicillium species } \\
\text { Fusarium species }\end{array}$ & $\begin{array}{l}\mathrm{C}-\mathrm{H} \\
\mathrm{C}=\mathrm{C} \\
\mathrm{C}=\mathrm{O}\end{array}$ & - & Umamaheswari and Murali (2013) \\
\hline Penicillium species & $\begin{array}{l}\mathrm{C}-\mathrm{H} \\
\mathrm{C}=\mathrm{C} \\
\mathrm{C}=\mathrm{O} \\
\mathrm{O}-\mathrm{H} \\
\mathrm{C}-\mathrm{O}-\mathrm{C}\end{array}$ & - & Umamaheswari and Murali (2013) \\
\hline Actinomyctes & - & $4.76 \%$ (Elongation increases) & Sharon and Sharon (2013) \\
\hline $\begin{array}{l}\text { Aspergillus oryzae } \\
\text { Trichoderma } \text { species } \\
\text { Neopestalotiopsis species } \\
\text { Fusarium species } \\
\text { Microsphaeropsis arundinis }\end{array}$ & Hydrolytic enzymes & $\begin{array}{l}1 \% \\
7 \% \\
0.4 \% \\
1.4 \% \\
4.1 \%\end{array}$ & Chaves et al. (2018) \\
\hline Penicillium funiculosum & Hydrolytic enzymes & $0.08 \%$ & Nowak et al. (2011) \\
\hline Humicola insolens & Cutinase enzyme & - & Carniel et al. (2017) \\
\hline
\end{tabular}




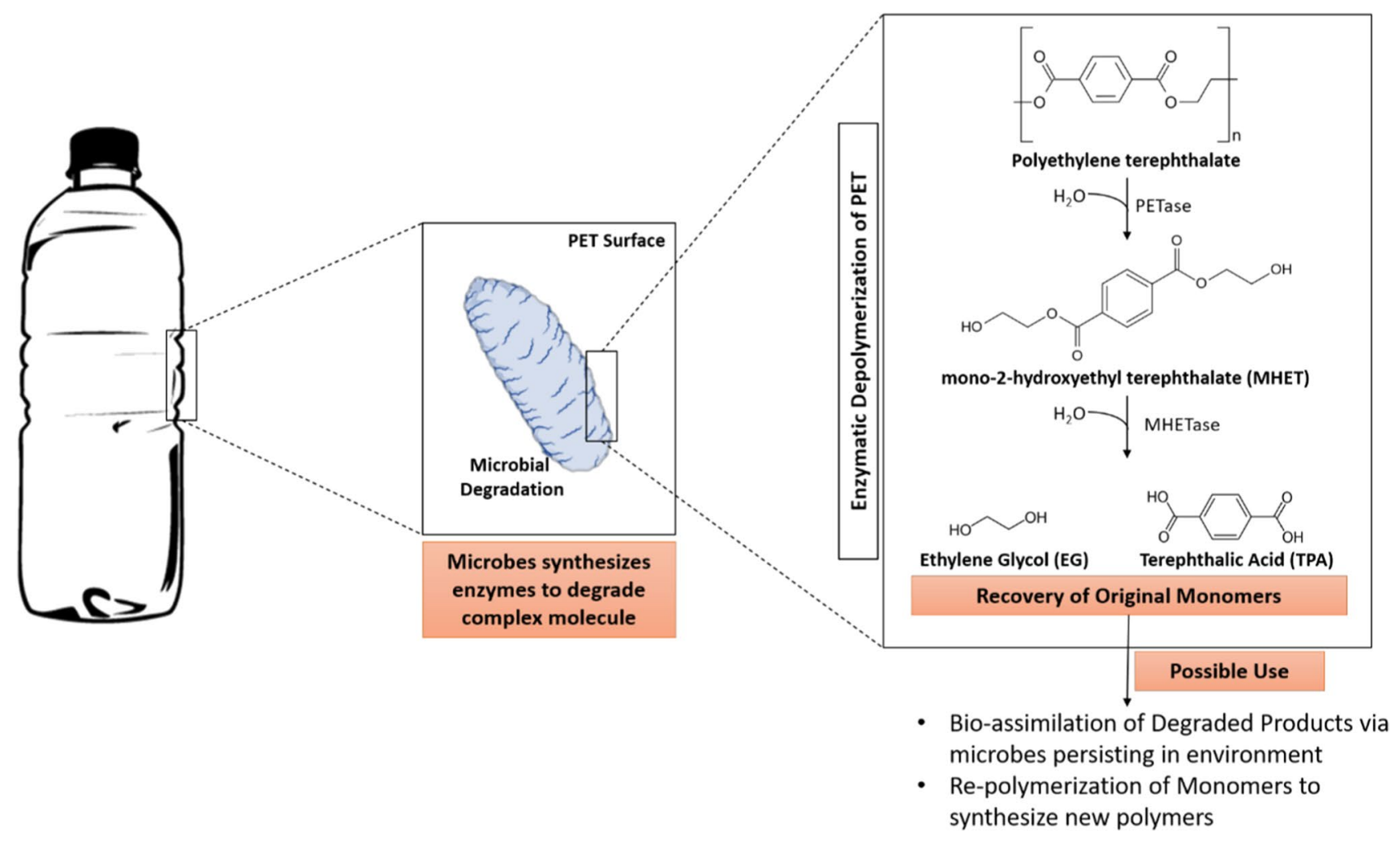

Fig. 2 Microbe-assisted degradation of polyethylene terephthalate and possible recovery of the degraded products

sediments (Razeghi et al. 2021). Moreover, the sample collection location is based on the problem under investigation and the platform for monitoring. A fixed vessel of opportunity like a ferry would produce more confined samples than a dedicated platform being used for the sole purpose of monitoring samples. Despite this, both the sampling platforms are considered equally valid. To increase the precision in selection of sample location and the sampling efficiency, information of environmental aspects of oceanic water such as the salinity assessment of water, the surface temperature of the water, surface water currents and bathymetry, combined with sound knowledge of potential litter sources like tourist beaches, route of ships and fishing grounds inflow of rivers, will provide valuable results. However, the quality of results is determined by the applicability of theoretically estimated information to be effective in real, a significant obstacle in sampling. Moreover, the quantitative distribution of macro plastics in different water compartments is erratic. The ocean currents, changes in river discharge depending on different seasons, mechanisms of deconstruction of litter and variations in size, movement, shape and litter buoyancy are various aspects. Therefore, the key to obtaining effective results is to emphasize sampling design. Moreover, repetitive measurements and surveys can further demonstrate the variance in the system. In general, a minimum of triplicates is suggested to record the error and variance in the data.

\section{Sample collection of macroplastics from oceans}

Macro plastics are generally less abundant beneath the surface and widely distributed. Therefore, various sampling methodologies are used to collect macro-, meso- and microplastics from the environment. The first method involves the net tow using neuston net to collect the surface sample (KovačViršek et al. 2016). The second method uses Mega Net, which collects meso- and macro-plastics from the environment (Lebreton et al. 2018). The third method involves collecting bulk water samples in which a large volume of water is collected, and the volume is reduced to collect the litter (Song et al. 2014). The fourth one includes visualizing the floating marine litter on the sea's surface (Ryan 2013). The last one is the photographic and aerial surveys, in which visual survey is done using drone or aeroplane to collect the marine litter (Lebreton et al. 2018). Out of these five methods, visual examination is the most common method used to assess quantities and size of plastics litter.

\section{Factors affecting sample collection}

Various factors like temporal variation, large- to mediumscale spatial variations, medium- to small-scale spatial variations and baseline studies influence the distribution of plastic litter in the oceans. 
Table 3 Mechanisms of action of enzymes and genes suggested by various researchers for the degradation of polyethylene terephthalate

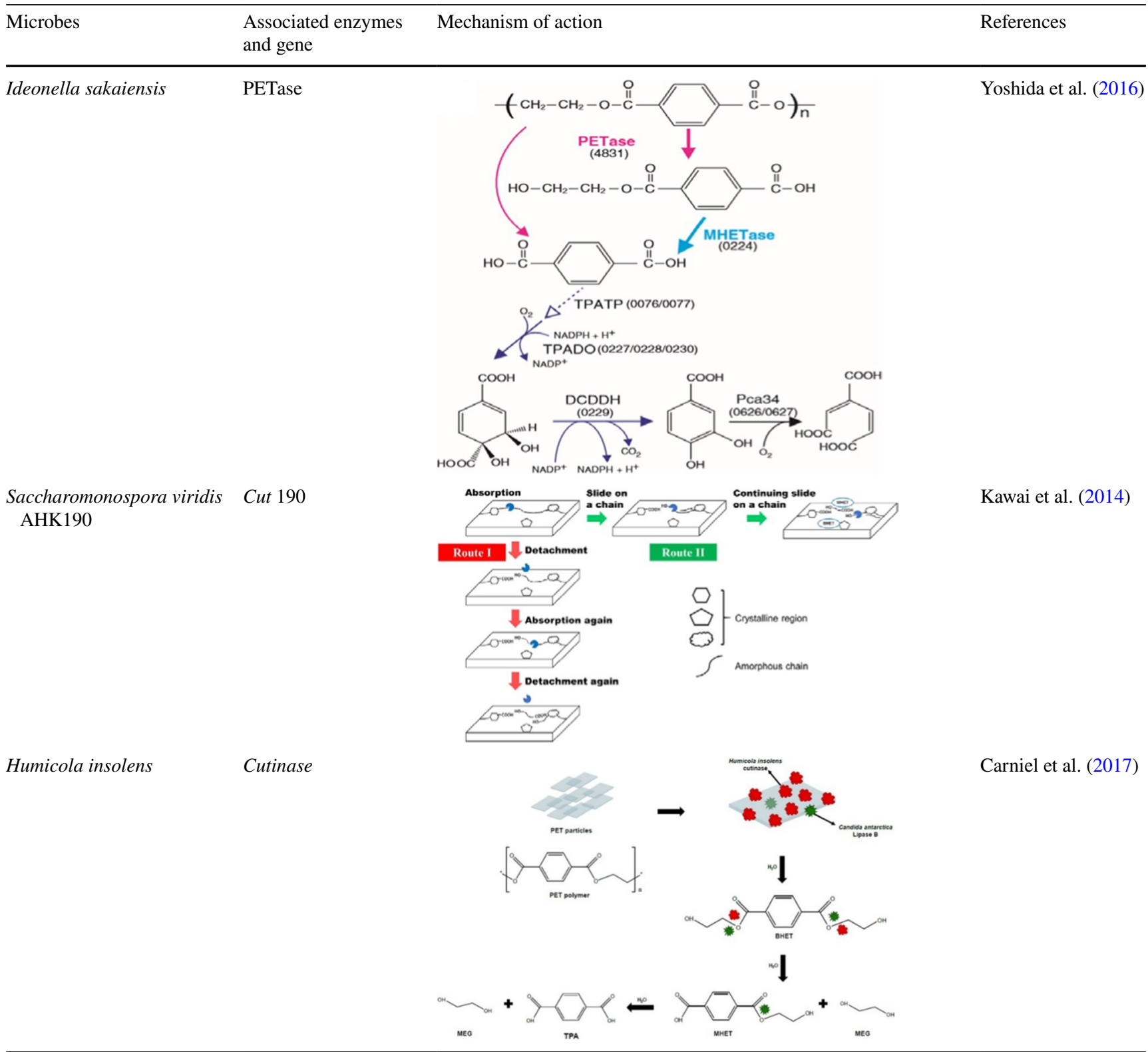

Temporal variations: various processes running daily as well as those extending to long periods such as extreme seasonal climate, short-duration wind and rainy events, and tidal conditions can significantly influence the distribution of macro plastics in oceans, which needs to be considered while deciding the sampling location, frequency and time (VanEmmerik et al. 2020).

Large- to medium-scale spatial variations: to measure the variance in surface water and water columns in river outflows, currents, urban outfalls, and direct beach inputs at meso and large-scale, different sampling locations are considered (Lebreton et al. 2018).

Medium- to small-scale spatial variations: this variability can be estimated by collecting short samples multiple times and then investigating the differences in the samples (KovačViršek et al. 2016).

Baseline studies: to further assist and form a basis for future sampling studies regarding the type of macro plastic litter and its quantitative dispersion in different water compartments, it is essential to record initial surveys and substantiate a baseline (Ryan 2013).

\section{Analytical techniques}

The breakdown of this polymer can be observed through changes in physical and chemical properties. Therefore, changes in these properties can be seen via different analytical techniques: scanning electron microscopy, 
gas-chromatography, high-performance liquid chromatography and near-infrared spectroscopy. Different techniques for the degradation of PET are well represented in Fig. 3. These techniques help in the recognition and quantification of the product formed as well as confirmed the degradation. Further analysis of gaseous products can be done using one of these techniques. However, along with the benefits, they also have some disadvantages (Table 4).

\section{Gas chromatography-mass spectroscopy}

Gas chromatography-mass spectroscopy (GC-MS) is one of the most common analytical techniques used to robustly identify a wide range of organic compounds at the micromolar level (Sørensen et al. 2021). It is a highly sensitive technique that allows us to identify various VOCs (Volatile organic compounds). Farzi et al. (2019) used GC-MS for identifying the metabolites produced in the PET degradation via Streptomyces species. O-xylene and ethyl benzene were the main metabolites identified after PET degradation. Although this enables us to identify the compounds, it cannot quantify the compound present in the sample. The GC-MS was used to quantify the hydrocarbons produced by marine bacteria after degrading PET. The hydrocarbons were phenanthrene, tetradecane, naphthalene and diesel (Denaro et al. 2020). Ultraviolet radiations cause fragmentation in synthetic and natural microfibres. The synthetic PET microfibre is degraded after exposure to $\mathrm{UV}$ and releases chemical additives as well as degradation products of polymer. GC-MS screened specific leached additives and degraded products. GC-MS is also reported for the analysis of acetaldehyde, the main degradation

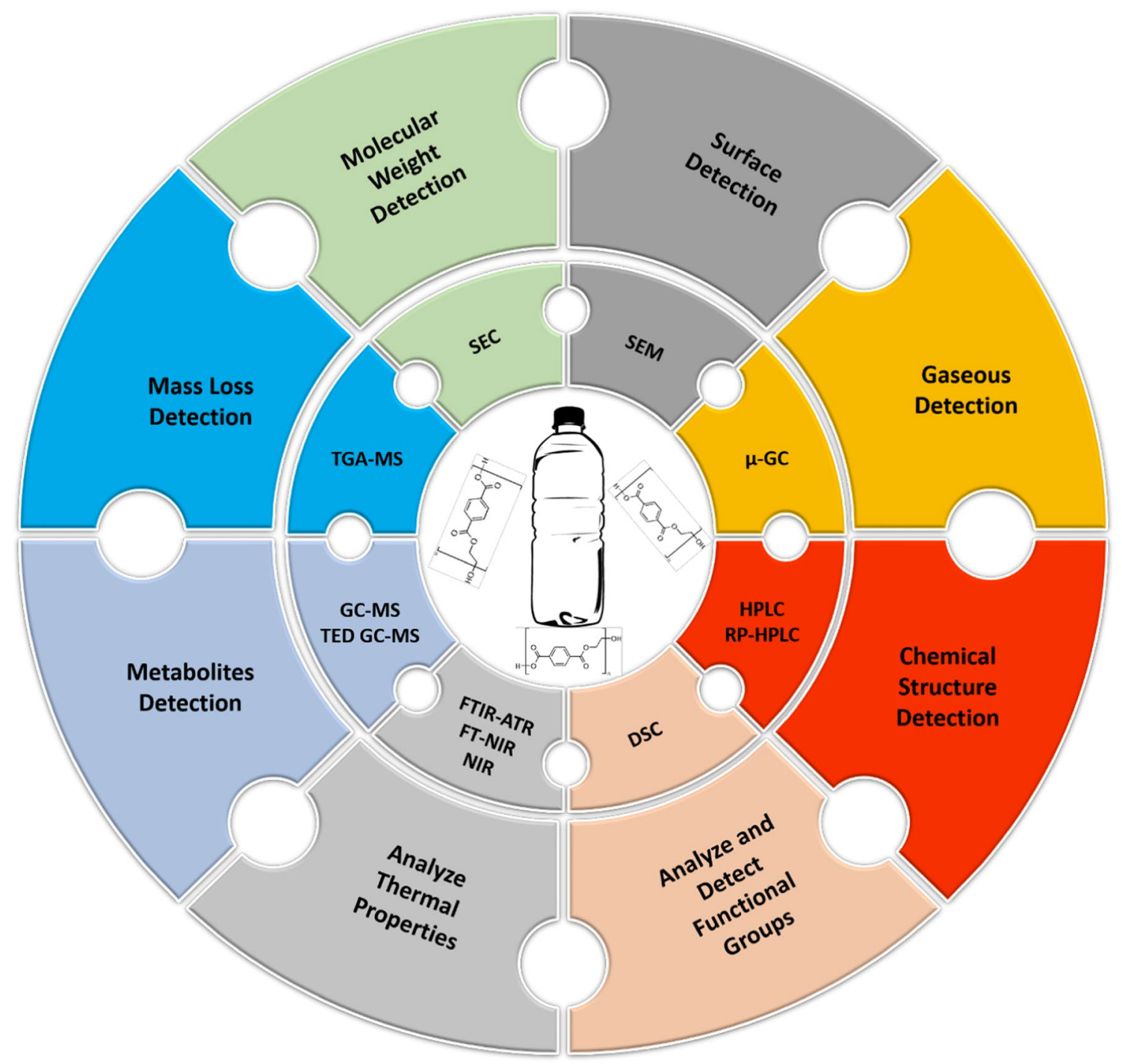

Fig. 3 Different analytical techniques for detection, characterization and confirmation of the metabolites and degraded polyethylene terephthalate in the environment 


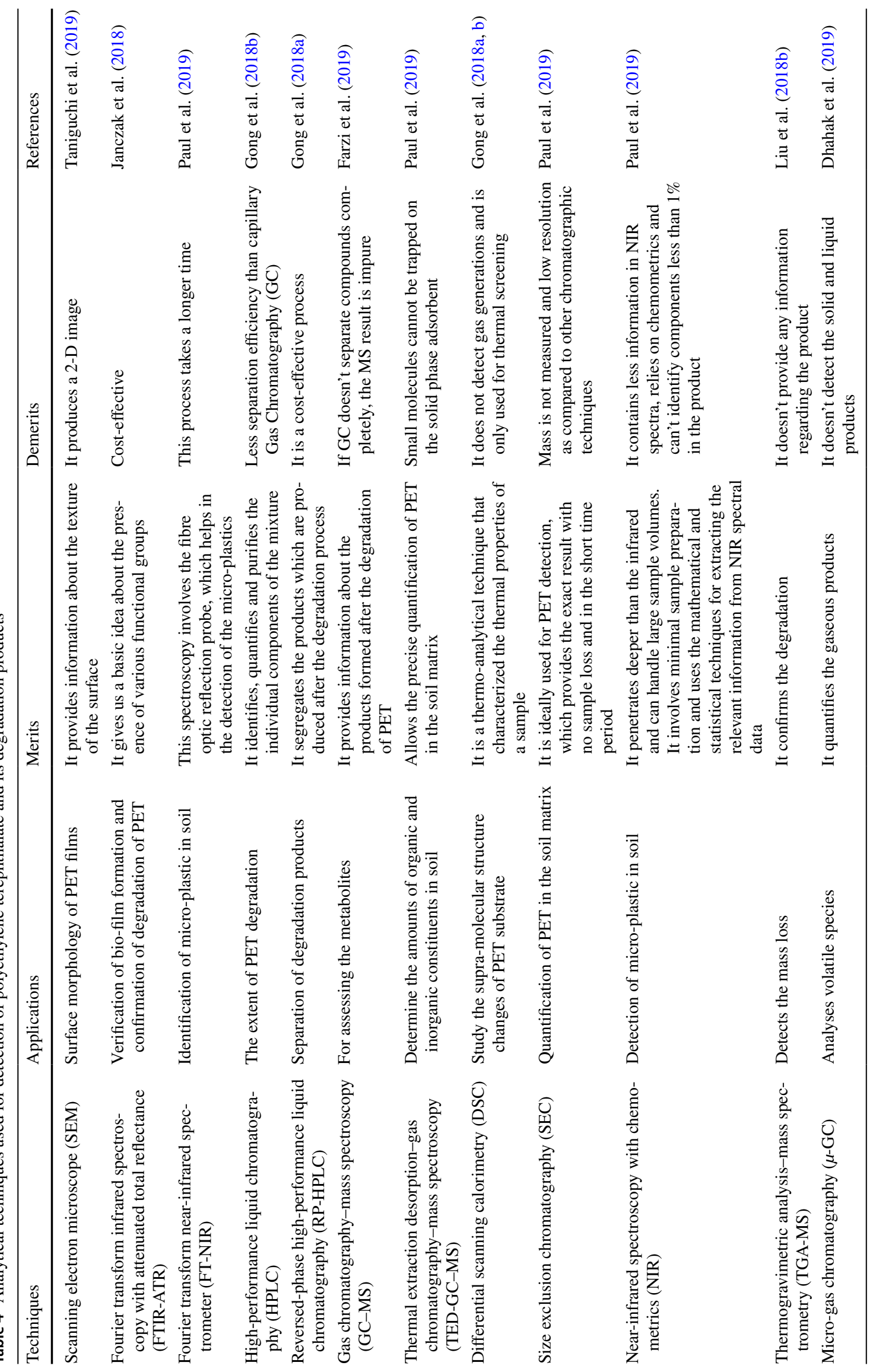


product or metabolite of PET. The terephthalic acid, 4-ethylbenzoic acid, vinyl benzoate, 4-acetylbenzoic acid, benzoic acid, 4-methylbenzoic acid, phenacyl formate, diethylene glycol dibenzoate and 1,2-ethanediol monobenzoate compounds were found (Sørensen et al. 2021). More studies on modification to sample preparation and instrument are needed as it would help in understanding the weathering of plastics as well as microbial degradation.

\section{Thermal extraction desorption gas chromatography-mass spectroscopy}

In thermal extraction desorption gas chromatography-mass spectroscopy (TED GC-MS), the sample is exposed to a high temperature before introducing the GC-MS for analysis (Qin et al. 2016). Then, as on heating, the sample liberates volatile organic compounds (VOCs). This technique measures the heating time for produced VOCs, identifies them, and quantifies the compounds produced (Liu et al. 2018b). Dümichen et al. (2017) used thermal extraction desorption gas chromatography-mass spectroscopy to determine the quantity of organic and inorganic components in the soil matrix, such as ethyl benzoate and vinyl benzoate. However, one major limitation is that smaller molecules less than C5 species cannot trap the solid-phase adsorbent. However, thermal extraction desorption gas chromatography-mass spectroscopy is a beneficial technique to detect the unknown species of the organic compound formed after the polymer degradation or to detect the microplastic in the samples (Duemichen et al. 2014). In this technique, firstly, the samples are heated in the thermo gravimetric balance and absorbed on solid-phase adsorber; from there, it is transferred to a thermal desorption unit. Then it is analysed with the mass selective detector followed by the separation through the chromatographic technique, which is easy to analyse a large sample of up to $100 \mathrm{mg}$ and needs less time for sample preparation (Duemichen et al. 2019).

\section{Micro-gas chromatography}

Micro-gas chromatography ( $\mu$-GC) is used to analyse and quantify online gaseous substances. Its principle is the same as gas chromatography, except that its different components are reduced to increase its analysis efficiency, portability and less power consumption (Regmi and Agah 2018). Methane, carbon monoxide, ethane, carbon dioxide, acetylene gases were identified by applying this technique (Dhahak et al. 2019). This technique helps detect the gases formed after the degradation process but does not give any idea about the non-volatile substances.

\section{Scanning electron microscopy}

Scanning electron microscopy (SEM) is an efficient technique for the qualitative assessment of polymeric materials to check microorganism's degradation ability. In this technique, a finely focused beam of electrons is used to scan the sample, resulting in secondary electrons that carry the information (L'Annunziata 2012). Liu et al. (2018a) used this technique to analyse the textural damages on PET film's surface and the biofilm formation caused by the WL-3 strain of Delftia species. Taniguchi et al. (2019) reported traces of PET film deterioration with SEM help while treating with Ideonella sakaiensis 201-F6 bacterial strain compared to the untreated control. However, it gives us information about the surface's texture, but it cannot provide us with a highresolution picture since it produces a $2 \mathrm{D}$ image. Hussein et al. (2018) explored the SEM for observing the holes or pit on the surface of PET after the degradation by bacteria named Acinetobacter baumannii. Another researcher also used this technique to observe microorganisms' presence and their degradation impact on the crystalline structure of PET (Sharon and Sharon 2013). Farzi et al. (2019) and Huang et al. (2018) examined the surface of PET under SEM to analyse the biodegradation by Streptomyces species and an enzyme PETase, respectively. With the help of SEM, Austin et al. (2018) observed the large pits on the surface of polyethylene-2,5-furandicarboxylate (PEF) treated with PETase, which is a homolog of PET. Vague et al. (2019) used this technique to observe the biofilm formation by microorganisms on the PET surface as it plays a significant role in biodegradation. SEM shows the unevenness and cracks on Agripack and Carton pack PET (AP and CP-PET) surface treated with an enzyme TfCut 2 from Thermobifida fusca (Wei et al. 2019). The cracks and mycelial adherence were observed on the surface of PET after the fermentation with Microsphaeropsis arundinis (Malafatti-Picca et al. 2019). SEM micrographs of PET provide insight into the cracks, stability of polymer and also information on the pollutants adsorbed onto their surface.

\section{Differential scanning calorimetry}

To characterize the thermal properties of PET, differential scanning calorimetry (DSC) comes into play. It helps us to study the changes in the molecular structure of PET. In the differential scanning calorimetry analytical technique, Nik Hassan et al. (2018) used nitrogen gas to prevent the oxidation of samples. An increment in melting point of $2{ }^{\circ} \mathrm{C}$ and $3{ }^{\circ} \mathrm{C}$ of high-density polyethylene with recycled PET 30\% and 50\% was observed. Several studies have been reported to study the thermal properties of PET particles. Gong et al. (2018a) explored this analytical technique to study PET particles' thermal properties, 
from which crystallinity was calculated. However, this technique lacks the ability to gives us information about gaseous substances. Chaisupakitsin et al. (2019) used this technique to measure the thermal properties of the PET coloured and transparent bottle after sunlight exposure. They determined PET bottles' melting temperature and fusion heat at the heating and cooling rate of $10{ }^{\circ} \mathrm{C} /$ min. Austin et al. (2018) observed the polyethylene2,5-furandicarboxylate (PEF) degradation by differential scanning calorimetry compared to the PET. PEF is a bioderived PET alternative with enhanced barrier properties.

Moreover, it was observed that PEF relative crystallinity reduced to $15.7 \%$ compared to the PET $10.1 \%$. At the same time, Wei et al. (2019) used differential scanning calorimetry for pet samples to obtain the cold crystallization and glass transition temperature along with the melting point. Ghorbantabar et al. (2021) used thermogravimetric analysis and differential scanning calorimetry to calculate the reaction conversion of PET waste degradation by the process of aminolysis. The obtained main product was bis(2-hydroxy ethylene) terephthalamide.

\section{Fourier transform infrared spectroscopy}

Fourier transform infrared spectroscopy (FTIR) coupled with attenuated total reflectance (ATR) focuses on several chemical group regions. The carbonyl group is more susceptible to the degradation process as it is a very reactive group, and it sometimes falls in the $1746 \mathrm{~cm}^{-1}$ region (Baker et al. 2014). It also explains the differences between the chemical structure of plastic bottles before and after treatment. Finally, it gives us information about the presence of functional groups. Most of the molecules absorb the light in the spectrophotometer's infrared region along the optical path and are absorbed by the sample when it undergoes internal reflection (Schuttlefield and Grassian, 2008). At the start, the carbonyl index is elevated as compared to the control due to oxidation, whereas, in the end, the number of carbonyl bonds declines, which decreases the carbonyl index. The carbonyl index was calculated as the ratio of the vibration band at $1712 \mathrm{~cm}^{-1}$ to that of $871 \mathrm{~cm}^{-1}$, corresponding to C-H vibrations in an aromatic ring (Janczak et al. 2018). Chaisupakitsin et al. (2019) used the FTIR technique to analyse the PET samples after sunlight exposure, whereas Fuller and Gautam (2016) used this technique to identify the compounds from PET. Vague et al. (2019) observed the spectral changes by analysing the PET samples pretreated with UV before degradation. This technique is surface sensitive and best suited to observe the polymer's chemical structure changes (Jung et al. 2018).

\section{Fourier transform near-infrared spectroscopy}

Fourier transform near-infrared spectroscopy (FT-NIR) uses the reflection probe to record the spectrum. It helps us to detect the microplastic in the sample. Thus, a larger sample can be tested quickly, including soil mixtures containing polymer and pure soil. NIR (near infrared) lies between the infrared and ultraviolet regions of the electromagnetic spectrum (Paul et al. 2019).

\section{Near-infrared spectroscopy with chemometrics}

Infrared spectroscopy is further combined with a mathematical and statistical technique, i.e. chemometrics, to extract the exact information from this analytical result data. However, this process takes a longer time as compared to the FTIRATR. Paul et al. (2019) used chemometrics to analyse the data produced by near-infrared spectroscopy (NIRS). FTIRATR converts the raw data into the actual spectrum. It measures the properties of solid or thin-film surfaces. FT-NIR is used for the sample's chemical imaging, and combining its data with chemometrics helps us convert the computational data into statistical data. NIR spectroscopy detects the PET plastic, and its spectra were selected as one-dimensional data for the network of convolutional neural (Xia et al. 2021). Many new updates to FT-IR are made to observe and understand micro- and nanoplastics in a better way.

\section{High-performance liquid chromatography}

High-performance liquid chromatography (HPLC) is based on liquid chromatography in which separation occurs between the two phases, i.e. the mobile and stationary phase. Therefore, the sample constituents distribute themselves based on their ability between these two phases (Bélanger et al. 1997). In HPLC, the stationary phase is polar, whereas the mobile phase is non-polar; therefore, polar samples are retained strongly to column leading to the elution of nonpolar compounds. de Castro et al. (2017) explored the HPLC to quantify the amount of terephthalic acid (TA), mono2-hydroxyethylterephthalate, bis-2-hydroxyethylterephthalate. However, for more accuracy and less time-consuming, RP-HPLC is used.

In reversed-phase chromatography, as its name suggests, phases get reversed in nature, i.e. the mobile phase is polar, and the stationary phase is non-polar. Hence, nonpolar compounds are retained for a more extended period on the column (Kucera 1986). Hantani et al. (2018) used RP-HPLC to analyse the enzymatic hydrolysis products of bis(2-hydroxyethyl) terephthalate, and as a result, terephthalic acid and mono-2-hydroxyethylterephthalate molecules were found. Gong et al. (2018a, b) separate the products of PET after the degradation process at a flow rate of $1 \mathrm{ml} / \mathrm{min}$ 
with the help of reversed phase (RP), and detection was done using HPLC at $240 \mathrm{~nm}$ wavelength. However, this process involves high costs.

Furthermore, this technique was used by Barth et al. (2015) to separate the hydrolysis products of PET and separated them at $241 \mathrm{~nm}$ wavelength. Majorly found product was mono-2-hydroxyethylterephthalate for the account of $75 \%$ total hydrolysis product, i.e. $0.55 \mathrm{~g}$ of mono-2-hydroxyethylterephthalate in $1 \mathrm{~g}$ PET. First, HPLC separates the samples based on their molecular weight and polarity. Then, the mixture of the compounds separates them into their components.

Alberto Lopes et al. (2021) quantified the six PET oligomers in coffee capsules extract which are non-intentionally added substances via HPLC-UV/FLD method. All six oligomers were composed of terephthalic acid, ethylene glycol, dimer, trimer, tetramer, pentamer, hexamer and heptamer.

\section{Size exclusion chromatography}

Size exclusion chromatography (SEC) is used to assess the polymeric characteristics of the polymers and separate various compounds based on their size (Kostanski et al. 2004). It separates different macro- and micro-molecules or mixtures of organic polymers (Moldoveanu and David 2016). It separates the analytes or molecules based on their size. It depends upon the behaviour of solubility of different polymers. Size exclusion chromatography is beneficial to extract a single chemical from the mixture (Elert et al. 2017). For PET, changes in molecular mass can be observed using this technique (Paul et al. 2019). It gives us an idea about the existing molar mass of polymer content. However, it does not tell us about the exact mass of the samples. Arhant et al. (2019) used this technique to determine the molar mass of the degraded products formed after hydrolytic degradation of PET. Vaverkova et al. (2018) calculated the molar mass of the PET polyester using this technique after degrading this under the composting laboratory conditions. For analysing the molecular weight of post-consumer, PET was detected by using SEC after chemical degradation (Amaro et al. 2015). SEC is a separation technique that separates different types of molecules based on their size. This technique estimates or quantifies the PET and PS presence in the sample and determines the molar mass.

\section{Thermogravimetric analysis-mass spectroscopy}

Thermogravimetric analysis-mass spectroscopy (TGA-MS) measures mass losses due to degradation during the analysis. If a mass spectroscopy is connected to the thermogravimetric analysis, we can also have chemical information on the released substances during the analysis. It is also used to study the polymer, viz. important parameters, heating rate, final temperature and flow rate. However, this does not provide information regarding the product. Pyrolysis of PET was studied using this analytical technique to investigate these conditions mentioned above, which are required in the tubular reactor (Dhahak et al. 2019). Divinyl terephthalate, mono-vinyl terephthalate, benzene, toluene and terephthalic acid were the primarily identified products at $435^{\circ} \mathrm{C}$ temperature pyrolysis using thermogravimetric analysis-mass spectroscopy analysis (Hujuri et al. 2013). It is further explored by Liu et al. (2018b) to detect the volatile organic compounds composition during the thermal degradation of PET fibres and popcorn. It was observed that the methylbenzene, styrene, formaldehyde, acetaldehyde and benzaldehyde compounds were present (Liu et al. 2018b). David et al. (2018) explored this technique for the PET micro-plastic quantitative analysis in soil. Thermogravimetric analysis-mass spectroscopy is a technique that provides information only about the mass loss, not the product formed. However, it ensures the degradation of the PET.

\section{Ultra-high-performance liquid chromatography- quadrupole time-of-flight mass spectrometry (UHPLC- qTOF-MS)}

This technique was applied to quantify the PET cyclic dimer to heptamer substances that migrated from the teabags made up of PET into food and water simulants. They have detected the all-cyclic oligomers in the PET first series, composed of terephthalic acid and ethylene glycol dimer, trimer, tetramer, pentamer, hexamer and heptamer (Tsochatzis et al. 2020).

Ultra-performance liquid chromatography coupled mass spectroscopy detection with quadrupole-time-of-flight mass analyser (UPLC-MS-QTOF) technique was used to identify and quantify the oligomers profile, non-volatile additives and other non-intentionally added substances. Ubeda et al. (2018) determined the oligomers from virgin and recycled PET samples. They have recommended the total dissolution method using methanol or hexafluoro-2-propanol as an antisolvent and solvent system for preparing the samples. This method was preferable to quantify and identify the potential migrants from PET samples. They have detected the four lineal and ten cyclic oligomers composed of ethylene glycol, diethylene glycol and terephthalic acid. Along with this, pentamers, tetramers, trimers and dimers were also observed.

\section{Conclusion}

Plastic bottle utilization is essential in our day-by-day life. It has made our lives simpler by helping us from various perspectives because it is lightweight and easy to carry. 
Unfortunately, our earth is suffocatedby plastic pollution, and we are getting dependent on it. It is so pervasive that PET is one of the most widely manufactured plastics today. However, its management is turning into danger in the present situation and an imperative reason for the pollution. It disturbs the environment in many ways by affecting the air, soil and water quality. This PET plastic's burning releases harmful gases such as nitric oxide, sulphur dioxide and chlorofluorocarbon. Also, it renders the soil less fertile for the production of crops.

Furthermore, it causes hormonal imbalance, cancer, nervous system disorders and immunity level reduction in human beings. The ingestion of PET microplastics by vertebrates and invertebrates is the prominent reason for their fatal internal injuries. There are numerous approaches to coping with this problem; however, the most acknowledged and eco-friendly technique is biodegradation. Destabilizing the electric charge with the help of microbial enzymes prompts the PET plastic to break down. Microorganisms can degrade PET plastic, which is an effective way to minimize plastic pollution. In addition, microbes can mineralize PET plastic for their growth, energy and nutritional purposes. Native microbes (bacteria or fungi) can be isolated from the plastic dumping site or the sewage water. As the microbial communities are present, there will be more efficient in degrading plastics. In addition, the microorganisms present in these areas will have unique enzymes and activity to degrade the PET plastic and their respective monomers.

Acknowledgements Authors are highly grateful to the Head, Department of Microbiology, School of Bioengineering and Biosciences, Lovely Professional University, for providing necessary research facilities.

Author contributions VD and SS have contributed in exploring literature and writing. JS and VD conceptualized, and acquired the entire concept and guided the authors for writing this review. VD, SS, JS, SG, AGA, SKN, MK, and PCR have made the contributions including drafting and data verification under the leadership of Prof. JS and Prof. PCR (Corresponding authors). All authors read and approved the final manuscript.

Funding Funding was provided by Indian Institute of Science (Grant No. IE/REAC-20-0134).

Data availability The raw or processed data required to reproduce these findings cannot be shared at this time as the data also form part of an ongoing study.

\section{Declarations}

Conflict of interest The authors have no potential conflict of interest to declare.

Ethical approval This article does not contain any studies with animals performed by any of the authors.
Consent for publication On behalf of authors, Prof. Joginder Singh has been given authorization to submit and correspond.

\section{References}

Ahmadinia E, Zargar M, Karim MR et al (2012) Performance evaluation of utilization of waste polyethylene terephthalate (PET) in stone mastic asphalt. Constr Build Mater 36:984-989. https://doi. org/10.1016/j.conbuildmat.2012.06.015

Acero EH, Ribitsch D, Steinkellner G et al (2011) Enzymatic surface hydrolysis of PET: effect of structural diversity on kinetic properties of cutinases from Thermobifida. Macromolecules 44:46324640. https://doi.org/10.1021/ma200949p

Alberto Lopes J, Tsochatzis ED, Karasek L et al (2021) Analysis of PBT and PET cyclic oligomers in extracts of coffee capsules and food simulants by a HPLC-UV/FLD method. Food Chem 345:128739. https://doi.org/10.1016/j.foodchem.2020.128739

Alvarado Chacon F, Brouwer MT, Thoden van Velzen EU (2020) Effect of recycled content and rPET quality on the properties of PET bottles, part I: optical and mechanical properties. PackagTechnol Sci 33:347-357. https://doi.org/10.1002/pts.2490

Alzuhairi MAH, Khalil BI, Hadi RS (2017) Nano ZnO Catalyst for Chemical Recycling of Polyethylene terephthalate (PET). EngTechnol J 35:831-837

Amaro LP, Coiai S, Ciardelli F, Passaglia E (2015) Preparation and testing of a solid secondary plasticizer for PVC produced by chemical degradation of post-consumer PET. Waste Manag 46:68-75. https://doi.org/10.1016/j.wasman.2015.09.005

Anadón A, Binderup ML, Bursch W et al (2011) Scientific Opinion on the criteria to be used for safety evaluation of a mechanical recycling process to produce recycled PET intended to be used for manufacture of materials and articles in contact with food. EFSA J 9:2184. https://doi.org/10.2903/j.efsa.2011.2184

Arhant M, Le Gall M, Le Gac PY, Davies P (2019) Impact of hydrolytic degradation on mechanical properties of PET-towards an understanding of microplastics formation. PolymDegrad Stab 161:175-182. https://doi.org/10.1016/j.polymdegradstab.2019. 01.021

Austin HP, Allen MD, Donohoe BS et al (2018) Characterization and engineering of a plastic-degrading aromatic polyesterase. Proc Natl Acad Sci USA 115:E4350-E4357. https://doi.org/10.1073/ pnas. 1718804115

Bach C, Dauchy X, Chagnon MC, Etienne S (2012) Chemical compounds and toxicological assessments of drinking water stored in polyethylene terephthalate (PET) bottles: a source of controversy reviewed. Water Res 46:571-583. https://doi.org/10.1016/j. watres.2011.11.062

Bach C, Dauchy X, Severin I et al (2013) Effect of temperature on the release of intentionally and non-intentionally added substances from polyethylene terephthalate (PET) bottles into water: chemical analysis and potential toxicity. Food Chem 139:672-680. https://doi.org/10.1016/j.foodchem.2013.01.046

Baker MJ, Trevisan J, Bassan P et al (2014) Using Fourier transform IR spectroscopy to analyze biological materials. Nat Protoc 9:1771-1791. https://doi.org/10.1038/nprot.2014.110

Ball GL, McLellan CJ, Bhat VS (2012) Toxicological review and oral risk assessment of terephthalic acid (TPA) and its esters: a category approach. Crit Rev Toxicol 42:28-67. https://doi.org/10. 3109/10408444.2011.623149

Barth M, Honak A, Oeser T et al (2016) A dual enzyme system composed of a polyester hydrolase and a carboxylesterase enhances the biocatalytic degradation of polyethylene terephthalate 
films. Biotechnol J 11:1082-1087. https://doi.org/10.1002/ biot. 201600008

Barth M, Oeser T, Wei R et al (2015) Effect of hydrolysis products on the enzymatic degradation of polyethylene terephthalate nanoparticles by a polyester hydrolase from Thermobifidafusca. BiochemEng J 93:222-228. https://doi.org/10.1016/j.bej.2014. 10.012

Barthélémy E, Spyropoulos D, Milana MR et al (2014) Safety evaluation of mechanical recycling processes used to produce polyethylene terephthalate (PET) intended for food contact applications. Food Addit Contam Part A Chem Anal Control Expo Risk Assess 31:490-497. https://doi.org/10.1080/19440049. 2013.871755

Begley TH, Dennison JL, Hollifield HC (1990) Migration into food of polyethylene terephthalate (PET) cyclic oligomers from pet microwave susceptor packaging. Food Addit Contam 7:797803. https://doi.org/10.1080/02652039009373941

Bélanger JMR, Jocelyn Paré JR, Sigouin M (1997) Chapter 2 High performance liquid chromatography (HPLC): principles and applications. Tech Instrum Anal Chem 18:37-59. https://doi. org/10.1016/S0167-9244(97)80011-X

Bhargava S, Chen Lee SS, Min Ying LS, Neo ML, Lay-Ming Teo S, Valiyaveettil S (2018) Fate of nanoplastics in marine larvae: a case study using barnacles, Amphibalanus amphitrite. ACS Sustain Chem Eng 6:6932-6940. https://doi.org/10.1021/acssu schemeng. 8b00766

Besley A, Vijver MG, Behrens P, Bosker T (2017) A standardized method for sampling and extraction methods for quantifying microplastics in beach sand. Mar Pollut Bull 114:77-83. https://doi.org/10.1016/j.marpolbul.2016.08.055

Blašković A, Fastelli P, Čižmek H et al (2017) Plastic litter in sediments from the Croatian marine protected area of the natural park of Telašćica bay (Adriatic Sea). Mar Pollut Bull 114:583586. https://doi.org/10.1016/j.marpolbul.2016.09.018

Brandts I, Teles M, Tvarijonaviciute A, Pereira ML, Martins MA, Tort L, Oliveira M (2018) Effects of polymethylmethacrylate nanoplastics on Dicentrarchus labrax. Genomics 110:435-441. https://doi.org/10.1016/j.ygeno.2018.10.006

Brems A, Baeyens J, Beerlandt J, Dewil R (2011a) Thermogravimetric pyrolysis of waste polyethylene-terephthalate and polystyrene: a critical assessment of kinetics modelling. ResourConservRecycl 55:772-781. https://doi.org/10.1016/j.resconrec. 2011.03.003

Brems A, Baeyens J, Vandecasteele C, Dewil R (2011b) Polymeric cracking of waste polyethylene terephthalate to chemicals and energy. J Air Waste Manag Assoc 61:721-731. https://doi.org/ 10.3155/1047-3289.61.7.721

Carneado S, Hernández-Nataren E, López-Sánchez JF, Sahuquillo A (2015) Migration of antimony from polyethylene terephthalate used in mineral water bottles. Food Chem 166:544-550. https:// doi.org/10.1016/j.foodchem.2014.06.041

Carniel A, Valoni É, Nicomedes J et al (2017) Lipase from Candida antarctica (CALB) and cutinase from Humicola insolens act synergistically for PET hydrolysis to terephthalic acid. Process Biochem 59:84-90. https://doi.org/10.1016/j.procbio.2016.07.023

Central Pollution Control Board (2018) Life Cycle Assessment (LCA) Study of Plastics Packaging Product. 3:5-60. https://cpcb.nic.in/ uploads/plasticwaste/LCA_Report_15.05.2018.pdf

Cerkez I, Kocer HB, Worley SD et al (2016) Antimicrobial functionalization of poly(ethylene terephthalate) fabrics with waterborne N-halamine epoxides. J Appl Polym Sci. https://doi.org/10.1002/ app. 43088

Chaisupakitsin M, Chairat-Utai P, Jarusiripot C (2019) Degradation of polyethylene terephthalate bottles after long sunlight exposure. Songklanakarin J Sci Technol 41:259-264. https://doi.org/10. 14456/sjst-psu.2019.32
CPCB (2015) Assessment and Characterisation of Plastic Waste Generation in 60 Major Cities. https://cpcb.nic.in/displaypdf.php? id=cGxhc3RpY3dhc3RIL1BXXzYwX2NpdGllc19yZXBvcnQtS mFuLTIwMTUucGRm

Chaves MRB, Lima MLSO, Malafatti-Picca L et al (2018) A practical fluorescence-based screening protocol for polyethylene terephthalate degrading microorganisms. J Braz Chem Soc 29:12781285. https://doi.org/10.21577/0103-5053.20170224

Chen G, Van Straalen NM, Roelofs D (2016) The ecotoxicogenomic assessment of soil toxicity associated with the production chain of 2,5-furandicarboxylic acid (FDCA), a candidate bio-based green chemical building block. Green Chem 18:4420-4431. https://doi.org/10.1039/c6gc00430j

Chilton T, Burnley S, Nesaratnam S (2010) A life cycle assessment of the closed-loop recycling and thermal recovery of post-consumer PET. Resour Conserv Recycl 54:1241-1249. https://doi.org/10. 1016/j.resconrec.2010.04.002

Christiansen L, Jensen LR, Fojan P (2019) Electrospinning of nonwoven aerogel-polyethene terephthalate composite fiber mats by pneumatic transport. J Compos Mater 53:2361-2366. https://doi. org/10.1177/0021998319829889

Cincotta F, Verzera A, Tripodi G, Condurso C (2018) Non-intentionally added substances in PET bottled mineral water during the shelflife. Eur Food Res Technol 244:433-439. https://doi.org/10.1007/ s00217-017-2971-6

Crossman J, Hurley RR, Futter M, Nizzetto L (2020) Transfer and transport of microplastics from biosolids to agricultural soils and the wider environment. Sci Total Environ 724:138334. https:// doi.org/10.1016/j.scitotenv.2020.138334

Das P, Tiwari P (2019) Thermal degradation study of waste polyethylene terephthalate (PET) under inert and oxidative environments. Thermochim Acta 679:178340. https://doi.org/10.1016/j.tca. 2019.178340

David J, Steinmetz Z, Kučerík J, Schaumann GE (2018) Quantitative analysis of poly(ethylene terephthalate) microplastics in soil via thermogravimetry-mass spectrometry. Anal Chem 90:87938799. https://doi.org/10.1021/acs.analchem.8b00355

de Castro AM, Carniel A, Nicomedes Junior J et al (2017) Screening of commercial enzymes for poly(ethylene terephthalate) (PET) hydrolysis and synergy studies on different substrate sources. J Ind Microbiol Biotechnol 44:835-844. https://doi.org/10.1007/ s10295-017-1942-z

Denaro R, Aulenta F, Crisafi F et al (2020) Marine hydrocarbondegrading bacteria breakdown poly(ethylene terephthalate) (PET). Sci Total Environ 749:141608. https://doi.org/10.1016/j. scitotenv.2020.141608

Dhahak A, Hild G, Rouaud M et al (2019) Slow pyrolysis of polyethylene terephthalate: online monitoring of gas production and quantitative analysis of waxy products. J Anal Appl Pyrolysis 142:104664. https://doi.org/10.1016/j.jaap.2019.104664

Dimitrov N, KratofilKrehula L, PtičekSiročić A, Hrnjak-Murgić Z (2013) Analysis of recycled PET bottles products by pyrolysisgas chromatography. Polym Degrad Stab 98:972-979. https:// doi.org/10.1016/j.polymdegradstab.2013.02.013

Dodson GZ, Shotorban AK, Hatcher PG et al (2020) Microplastic fragment and fiber contamination of beach sediments from selected sites in Virginia and North Carolina, USA. Mar Pollut Bull. https://doi.org/10.1016/j.marpolbul.2019.110869

Dong S, Qu M, Rui Q, Wang D (2018) Combinational effect of titanium dioxide nanoparticles and nanopolystyrene particles at environmentally relevant concentrations on nematode Caenorhabditis elegans. Ecotoxicol Environ Saf 161:444-450. https:// doi.org/10.1016/j.ecoenv.2018.06.021

Duemichen E, Braun U, Senz R et al (2014) Assessment of a new method for the analysis of decomposition gases of polymers by a combining thermogravimetric solid-phase extraction and 
thermal desorption gas chromatography mass spectrometry. J Chromatogr A 1354:117-128. https://doi.org/10.1016/j. chroma.2014.05.057

Duemichen E, Eisentraut P, Celina M, Braun U (2019) Automated thermal extraction-desorption gas chromatography mass spectrometry: a multifunctional tool for comprehensive characterization of polymers and their degradation products. J Chromatogr A 1592:133-142. https://doi.org/10.1016/j.chroma.2019.01.033

Dümichen E, Eisentraut P, Bannick CG et al (2017) Fast identification of microplastics in complex environmental samples by a thermal degradation method. Chemosphere 174:572-584. https://doi.org/ 10.1016/j.chemosphere.2017.02.010

Ekvall MT, Lundqvist M, Kelpsiene E et al (2019) Nanoplastics formed during the mechanical breakdown of daily-use polystyrene products. Nanoscale Adv 1:1055-1061. https://doi.org/10.1039/c8na0 $0210 \mathrm{j}$

Elert AM, Becker R, Duemichen E et al (2017) Comparison of different methods for MP detection: What can we learn from them, and why asking the right question before measurements matters? Environ Pollut 231:1256-1264. https://doi.org/10.1016/j.envpol. 2017.08.074

Eriksen M, Lebreton LCM, Carson HS et al (2014) Plastic pollution in the World's Oceans: more than 5 trillion plastic pieces weighing over 250,000 tons afloat at sea. PLoSOne. https://doi.org/10. 1371/journal.pone.0111913

European Union (2011) Commission Regulation (EU) No 10/2011 of 14 January 2011. Off J Eur Union Special ed:1-89. https://eurlex.europa.eu/legal-content/EN/TXT/PDF/?uri=CELEX:32011 R0010\&from $=\mathrm{EN}$

Everaert G, Van Cauwenberghe L, De Rijcke M et al (2018) Risk assessment of microplastics in the ocean: modelling approach and first conclusions. Environ Pollut 242:1930-1938. https://doi. org/10.1016/j.envpol.2018.07.069

Farzi A, Dehnad A, Fotouhi AF (2019) Biodegradation of polyethylene terephthalate waste using Streptomyces species and kinetic modeling of the process. Biocatal Agric Biotechnol 17:25-31. https://doi.org/10.1016/j.bcab.2018.11.002

Ferreira M, Thompson J, Paris A et al (2020) Presence of microplastics in water, sediments and fish species in an urban coastal environment of Fiji, a Pacific small island developing state. Mar Pollut Bull. https://doi.org/10.1016/j.marpolbul.2020.110991

Foolmaun RK, Ramjeeawon T (2013) Comparative life cycle assessment and social life cycle assessment of used polyethylene terephthalate (PET) bottles in Mauritius. Int J Life Cycle Assess 18:155-171. https://doi.org/10.1007/s11367-012-0447-2

Fuller S, Gautam A (2016) A procedure for measuring microplastics using pressurized fluid extraction. Environ Sci Technol 50:57745780. https://doi.org/10.1021/acs.est.6b00816

Gaikwad KK, Singh S, Lee YS (2018) Oxygen scavenging films in food packaging. Environ Chem Lett 16:523-538. https://doi.org/10. 1007/s10311-018-0705-z

Gaikwad KK, Singh S, Ajji A (2019) Moisture absorbers for food packaging applications. Environ Chem Lett 17:609-628. https://doi. org/10.1007/s10311-018-0810-z

Gaikwad KK, Singh S, Negi YS (2020) Ethylene scavengers for active packaging of fresh food produce. Environ Chem Let 18:269-284. https://doi.org/10.1007/s10311-019-00938-1

Galgani F (2019) Litter in the Mediterranean Sea. In: Komatsu T, Ceccaldi HJ, Yoshida J, Prouzet P, Henocque Y (eds) Oceanography challenges to future earth. Springer, Cham, pp 55-67. https://doi. org/10.1007/978-3-030-00138-4_6

Ganeshan G, Shadangi KP, Mohanty K (2018) Degradation kinetic study of pyrolysis and co-pyrolysis of biomass with polyethylene terephthalate (PET) using Coats-Redfern method. J Therm Anal Calorim 131:1803-1816. https://doi.org/10.1007/ s10973-017-6597-5
GESAMP (2019) Guidelines for the monitoring and assessment of plastic litter in the ocean. Rep Stud GESAMP no 99:130p. http:// www.gesamp.org/publications/guidelines-for-the-monitoringand-assessment-of-plastic-litter-in-the-ocean

Gewert B, Plassmann MM, Macleod M (2015) Pathways for degradation of plastic polymers floating in the marine environment. Environ Sci Process Impacts 17:1513-1521. https://doi.org/10. 1039/c5em00207a

Geyer R, Jambeck JR, Law KL (2017) Production, use, and fate of all plastics ever made. Sci Adv 3:25-29. https://doi.org/10.1126/ sciadv. 1700782

Ghorbantabar S, Ghiass M, Yaghobi N, Bouhendi H (2021) Investigation of conventional analytical methods for determining conversion of polyethylene terephthalate waste degradation via aminolysis process. J Mater Cycles Waste Manag 23:526-536. https://doi.org/10.1007/s10163-020-01149-5

Goel R, Jayal P, Negi H et al (2014) Comparative in situ PET biodegradation assay using indigenously developed consortia. Int J Environ Waste Manag 13:348-361. https://doi.org/10.1504/ IJEWM.2014.060441

Gomes TS, Visconte LLY, Pacheco EBAV (2019) Life cycle assessment of polyethylene terephthalate packaging: an overview. J Polym Environ 27:533-548. https://doi.org/10.1007/ s10924-019-01375-5

Gong J, Kong T, Li Y et al (2018a) Biodegradation of microplastic derived from poly(ethylene terephthalate) with bacterial wholecell biocatalysts. Polymers (basel) 10:1326. https://doi.org/10. 3390/polym10121326

Gong J, Li Y, Wang H et al (2018b) Depolymerization and assimilation of poly (ethylene terephthalate) by whole-cell bioprocess. In: IOP conference series: materials science and engineering. https://doi. org/10.1088/1757-899X/394/2/022047

Greifenstein M, White DW, Stubner A et al (2013) Impact of temperature and storage duration on the chemical and odor quality of military packaged water in polyethylene terephthalate bottles. Sci Total Environ 456-457:376-383. https://doi.org/10.1016/j. scitotenv.2013.03.092

Guo Z, Lindqvist K, de la Motte H (2018) An efficient recycling process of glycolysis of PET in the presence of a sustainable nanocatalyst. J Appl Polym Sci. https://doi.org/10.1002/app.46285

Hale RC, Seeley ME, La Guardia MJ et al (2020) A global perspective of microplastics. J Geophys Res Ocean 125:1-40. https://doi.org/ 10.1029/2018JC014719

Hantani Y, Imamura H, Yamamoto T et al (2018) Functional characterizations of polyethylene terephthalate-degrading cutinase-like enzyme Cut190 mutants using bis(2-hydroxyethyl) terephthalate as the model substrate. AIMS Biophys 5:290-302. https://doi. org/10.3934/biophy.2018.4.290

Heindler FM, Alajmi F, Huerlimann R et al (2017) Toxic effects of polyethylene terephthalate microparticles and $\mathrm{Di}(2$-ethylhexyl) phthalate on the calanoid copepod, Parvocalanus crassirostris. Ecotoxicol Environ Saf 141:298-305. https://doi.org/10.1016/j. ecoenv.2017.03.029

Horton AA, Svendsen C, Williams RJ et al (2017) Large microplastic particles in sediments of tributaries of the River Thames, UKAbundance, sources and methods for effective quantification. Mar Pollut Bull 114:218-226. https://doi.org/10.1016/j.marpo lbul.2016.09.004

Hu X, Thumarat U, Zhang X et al (2010) Diversity of polyester-degrading bacteria in compost and molecular analysis of a thermoactive esterase from Thermobifida alba AHK119. Appl Microbiol Biotechnol 87:771-779. https://doi.org/10.1007/s00253-010-2555-x

Huang X, Cao L, Qin Z et al (2018) Tat-independent secretion of polyethylene terephthalate hydrolase petase in Bacillus subtilis 168 mediated by its native signal peptide. J Agric Food Chem 66:13217-13227. https://doi.org/10.1021/acs.jafc.8b05038 
Hujuri U, Ghoshal AK, Gumma S (2013) Temperature-dependent pyrolytic product evolution profile for polyethylene terephthalate. J Appl Polym Sci 130:3993-4000. https://doi.org/10.1002/ app.39681

Hussein AA, Alzuhairi M, Aljanabi NH (2018) Degradation and depolymerization of plastic waste by local bacterial isolates and bubble column reactor. In: AIP conference proceedings. Am Inst Phy Inc 1968: 030081, https://doi.org/10.1063/1.5039268

Ingrao C, Lo Giudice A, Tricase C et al (2014) Recycled-PET fibre based panels for building thermal insulation: environmental impact and improvement potential assessment for a greener production. Sci Total Environ 493:914-929. https://doi.org/10. 1016/j.scitotenv.2014.06.022

Ingrao C, Scrucca F, Tricase C, Asdrubali F (2016) A comparative life cycle assessment of external wall-compositions for cleaner construction solutions in buildings. J Clean Prod 124:283-298. https://doi.org/10.1016/j.jclepro.2016.02.112

Intini F, Kühtz S (2011) Recycling in buildings: An LCA case study of a thermal insulation panel made of polyester fiber, recycled from post-consumer PET bottles. Int J Life Cycle Assess 16:306-315. https://doi.org/10.1007/s11367-011-0267-9

Jabarin SA (1982) Optical properties of thermally crystallized poly(ethylene terephthalate). PolymEng Sci 22:815-820. https:// doi.org/10.1002/pen.760221305

Janczak K, Hrynkiewicz K, Znajewska Z, Dąbrowska G (2018) Use of rhizosphere microorganisms in the biodegradation of PLA and PET polymers in compost soil. Int Biodeterior Biodegrad 130:65-75. https://doi.org/10.1016/j.ibiod.2018.03.017

Jung MR, Horgen FD, Orski SV et al (2018) Validation of ATR FT-IR to identify polymers of plastic marine debris, including those ingested by marine organisms. Mar Pollut Bull 127:704-716. https://doi.org/10.1016/j.marpolbul.2017.12.061

Kawai F, Oda M, Tamashiro $\mathrm{T}$ et al (2014) A novel $\mathrm{Ca}^{2+}$-activated, thermostabilized polyesterase capable of hydrolyzing polyethylene terephthalate from Saccharomonosporaviridis AHK190. Appl Microbiol Biotechnol 98:10053-10064. https://doi.org/10. 1007/s00253-014-5860-y

Keresztes S, Tatár E, Czégény Z et al (2013) Study on the leaching of phthalates from polyethylene terephthalate bottles into mineral water. Sci Total Environ 458-460:451-458. https://doi.org/10. 1016/j.scitotenv.2013.04.056

Komly CE, Azzaro-Pantel C, Hubert A et al (2012) Multi-objective waste management optimization strategy coupling life cycle assessment and genetic algorithms: application to PET bottles. Resour Conserv Recycl 69:66-81. https://doi.org/10.1016/j.resco nrec.2012.08.008

Kostanski LK, Keller DM, Hamielec AE (2004) Size-exclusion chromatography-a review of calibration methodologies. J BiochemBiophys Methods 58:159-186. https://doi.org/10.1016/j.jbbm. 2003.10.001

Koster S, Bani-Estivals MH, Bonuomo M et al (2015) Guidance on best practices on the risk assessment of non intentionally added substances (NIAS) in food contact materials and articles. In: Guid best Pract risk Assess non intentionally added Subst. food contact Mater. Artic. pp 68

Kosuth M, Mason SA, Wattenberg EV (2018) Anthropogenic contamination of tap water, beer, and sea salt. PLoSOne 13(4):e0194970. https://doi.org/10.1371/journal.pone.0194970

Koutsodendris A, Papatheodorou G, Kougiourouki O, Georgiadis M (2008) Benthic marine litter in four Gulfs in Greece, Eastern Mediterranean; abundance, composition and source identification. Estuar Coast Shelf Sci 77:501-512. https://doi.org/10. 1016/j.ecss.2007.10.011

KovačViršek M, Palatinus A, Koren Š et al (2016) Protocol for microplastics sampling on the sea surface and sample analysis. J vis Exp. https://doi.org/10.3791/55161
Kucera P (1986) Gradient elution in column liquid chromatography, theory and practice. J Chromatogr A 354:539-540. https://doi. org/10.1016/s0021-9673(01)87066-7

Kuczenski B, Geyer R (2013) PET bottle reverse logistics-environmental performance of California's CRV program. Int J Life Cycle Assess 18:456-471. https://doi.org/10.1007/ s11367-012-0495-7

L'Annunziata M (2012) Handbook of radioactivity analysis, 3rd edn. Elsevier USA

Lebreton L, Slat B, Ferrari F et al (2018) Evidence that the Great Pacific Garbage Patch is rapidly accumulating plastic. Sci Rep 8:1-15. https://doi.org/10.1038/s41598-018-22939-w

León-Zayas R, Roberts C, Vague M, Mellies JL (2019) Draft genome sequences of five environmental bacterial isolates that degrade polyethylene terephthalate plastic. Microbiol Resour Announc 8(25):e00237-e319. https://doi.org/10.1128/mra.00237-19

Lepoittevin B, Roger P (2011) Poly(ethylene terephthalate). In: Sabu T, Visakh PM (eds) Handbook of engineering and speciality thermoplastics polyethers and polyesters. Wiley, pp 97-126. https:// doi.org/10.1002/9781118104729.ch4

Li-Na J (2013) Study on preparation process and properties of polyethylene terephthalate (pet). Appl Mech Mater 312:406-410. https:// doi.org/10.4028/www.scientific.net/AMM.312.406

Lian F, Xing B, Zhu L (2011) Comparative study on composition, structure, and adsorption behavior of activated carbons derived from different synthetic waste polymers. J Colloid Interface Sci 360:725-730. https://doi.org/10.1016/j.jcis.2011.04.103

Lima GR, Monteiro WF, Scheid CM et al (2019) Evaluation of sodium/ protonated titanate nanotubes catalysts in virgin and post consumer PET depolymerization. Catal Lett 149:1415-1426. https:// doi.org/10.1007/s10562-019-02724-8

Liu J, Xu G, Dong W et al (2018a) Biodegradation of diethyl terephthalate and polyethylene terephthalate by a novel identified degrader Delftia sp. WL-3 and its proposed metabolic pathway. Lett Appl Microbiol 67:254-261. https://doi.org/10.1111/lam.13014

Liu S, Hu J, Qin D, et al (2018b) Analysis of the volatile organic compounds (VOCs) during the regeneration of post-consumed poly(ethylene terephthalate) using HS-GC-MS method. Materials Science Forum. pp 1208-1214. https://doi.org/10.4028/www. scientific.net/MSF.944.1208

Loulad S, Houssa R, Rhinane H et al (2017) Spatial distribution of marine debris on the seafloor of Moroccan waters. Mar Pollut Bull 124:303-313. https://doi.org/10.1016/j.marpolbul.2017. 07.022

Lykov AP, Poveshchenko OV, Surovtseva MA et al (2019) Effect of polyethylene terephthalate on functional properties of endothelial and mesenchymal cells. Bull Exp Biol Med 166:580-585. https:// doi.org/10.1007/s10517-019-04395-2

Ma J, Yu L, Chen S et al (2019) Structure-property evolution of poly(ethylene terephthalate) fibers in industrialized process under complex coupling of stress and temperature field. Macromolecules 52:565-574. https://doi.org/10.1021/acs.macromol. 8 b01561

Maes T, Barry J, Leslie HA et al (2018) Below the surface: twenty-five years of seafloor litter monitoring in coastal seas of North West Europe (1992-2017). Sci Total Environ 630:790-798. https:// doi.org/10.1016/j.scitotenv.2018.02.245

Malafatti-picca L, Ricardo M, Chaves DB et al (2019) Hydrocarbonassociated substrates reveal promising fungi for Poly (ethylene terephthalate) (PET) depolymerization. Braz J Microbiol 2050:1-28. https://doi.org/10.1007/s42770-019-00093-3

Mason SA, Welch VG, Neratko J (2018) Synthetic polymer contamination in bottled water. Front Chem 6:407. https://doi.org/10.3389/ fchem.2018.00407

Mintenig SM, Löder MGJ, Primpke S, Gerdts G (2019) Low numbers of microplastics detected in drinking water from ground 
water sources. Sci Total Environ 648:631-635. https://doi.org/ 10.1016/j.scitotenv.2018.08.178

Mohd Ishak ZA, Gatos KG, Karger-Kocsis J (2006) On the in-situ polymerization of cyclic butylene terephthalate oligomers: DSC and rheological studies. Polym Eng Sci 46:743-750. https://doi. org/10.1002/pen.20486

Moldoveanu SC, David V (2016) Selection of the HPLC method in chemical analysis, 1st edn. Elsevier Netherlands, pp 1-538

Morris BA (2016) The science and technology of flexible packaging: multilayer films from resin and process to end use. William Andrew (Elsevier), United Kingdom, pp 1-744

Mountford AS, Morales Maqueda MA (2019) Eulerian modeling of the three-dimensional distribution of seven popular microplastic types in the global ocean. J Geophys Res Ocean 124:8558-8573. https://doi.org/10.1029/2019JC015050

Muncke J, Backhaus T, Geueke B et al (2017) Scientific challenges in the risk assessment of food contact materials. Environ Health Perspect. https://doi.org/10.1289/EHP644

Nabid MR, Bide Y, Jafari M (2019) Boron nitride nanosheets decorated with $\mathrm{Fe}_{3} \mathrm{O}_{4}$ nanoparticles as a magnetic bifunctional catalyst for post-consumer PET wastes recycling. Polym Degrad Stab 169:108962. https://doi.org/10.1016/j.polymdegradstab.2019. 108962

Nakatani J, Fujii M, Moriguchi Y, Hirao M (2010) Life-cycle assessment of domestic and transboundary recycling of post-consumer PET bottles. Int J Life Cycle Assess 15:590-597. https://doi.org/ 10.1007/s11367-010-0189-y

Nanda S, Berruti F (2021a) Thermochemical conversion of plastic waste to fuels: a review. Environ Chem Lett 19:123-148. https:// doi.org/10.1007/s10311-020-01094-7

Nanda S, Berruti F (2021b) Municipal solid waste management and landfilling technologies: a review. Environ Chem Lett 19:14331456. https://doi.org/10.1007/s10311-020-01100-y

Nerin C, Alfaro P, Aznar M, Domeño C (2013) The challenge of identifying non-intentionally added substances from food packaging materials: a review. Anal Chim Acta 775:14-24. https://doi.org/ 10.1016/j.aca.2013.02.028

Hassan NRN, Ismail NM, Ghazali S, Nuruzzaman DM (2018) Thermal properties of polyethylene reinforced with recycled-poly (ethylene terephthalate) flakes. In: IOP conference series: materials science and engineering. 342: 012094. https://doi.org/10.1088/ 1757-899X/342/1/012094

Nixon J, Menary GH, Yan S (2017) Free-stretch-blow investigation of poly(ethylene terephthalate) over a large process window. Int J Mater Form 10:765-777. https://doi.org/10.1007/ s12289-016-1318-3

Nowak B, Pająk J, Labuzek S et al (2011) Biodegradation of poly(ethylene terephthalate) modified with polyester "Bionolle $₫$ " by Penicillium funiculosum. Polimery/polymers 56:35-44. https://doi.org/10.14314/polimery.2011.035

Othman AR, Hasan HA, Muhamad MH et al (2021) Microbial degradation of microplastics by enzymatic processes: a review. Environ Chem Lett 19:3057-3073. https://doi.org/10.1007/ s10311-021-01197-9

Paul A, Wander L, Becker R et al (2019) High-throughput NIR spectroscopic (NIRS) detection of microplastics in soil. Environ Sci Pollut Res 26:7364-7374. https://doi.org/10.1007/ s11356-018-2180-2

Prata JC (2018) Airborne microplastics: consequences to human health? Environ Pollut 234:115-126. https://doi.org/10.1016/j. envpol.2017.11.043

Qi Y, Beriot N, Gort G et al (2020a) Impact of plastic mulch film debris on soil physicochemical and hydrological properties. Environ Pollut 266:115097. https://doi.org/10.1016/j.envpol.2020.115097

Qi Y, Ossowicki A, Yang X et al (2020b) Effects of plastic mulch film residues on wheat rhizosphere and soil properties. $J$
Hazard Mater 387:121711. https://doi.org/10.1016/j.jhazmat. 2019.121711

Qin D, Wang C, Wang H (2016) Effect of azo dyes on the thermal degradation of post-consumer polyester fabrics. In: MATEC web of conferences. 67: 06053. https://doi.org/10.1051/matec conf $/ 20166706053$

Raheem AB, Bin HA, Noor ZZ et al (2018) Process simulation of bis (2-Hydroxyethyl) terephthalate and its recovery using two-stage evaporation systems. Chem Eng Trans 63:655-660. https://doi.org/10.3303/CET1863110

Raheem AB, Noor ZZ, Hassan A et al (2019) Current developments in chemical recycling of post-consumer polyethylene terephthalate wastes for new materials production: a review. J Clean Prod 225:1052-1064. https://doi.org/10.1016/j.jclepro.2019. 04.019

Rane PC, More AP, Mhaske ST (2018) Synthesis of a novel polyetheramide-polyaniline -composite anticorrosive coating from PET waste and jatropha oil. Indian J Chem Technol 25:539-545

Razeghi N, Hamidian AH, Wu C et al (2021) Microplastic sampling techniques in freshwaters and sediments: a review. Environ Chem Lett 19:4225-4252. https://doi.org/10.1007/s10311-021-01227-6

Regmi BP, Agah M (2018) Micro gas chromatography: an overview of critical components and their integration. Anal Chem 90:1313313150. https://doi.org/10.1021/acs.analchem.8b01461

Rezende LCSH, de Oliveira JH, Zart VPM et al (2019) Synthesis of metal nanoparticles for use as nanocatalysts in pet recycling. Acta Sci Technol 41:e37303. https://doi.org/10.4025/actascitec hnol.v41i1.37303

Ribitsch D, Acero EH, Greimel K et al (2012a) Characterization of a new cutinase from Thermobifida alba for PET-surface hydrolysis. Biocatal Biotransformation. https://doi.org/10.3109/10242422. 2012.644435

Ribitsch D, Acero EH, Greimel K et al (2012b) A new esterase from Thermobifidahalotolerans hydrolyses polyethylene terephthalate (PET) and polylactic acid (PLA). Polymers (basel) 4:617-629. https://doi.org/10.3390/polym4010617

Romero-Hernández O, Romero Hernández S, Muñoz D et al (2009) Environmental implications and market analysis of soft drink packaging systems in Mexico. A waste management approach. Int J Life Cycle Assess 14:107-113. https://doi.org/10.1007/ s11367-008-0053-5

Ryan PG (2013) A simple technique for counting marine debris at sea reveals steep litter gradients between the Straits of Malacca and the Bay of Bengal. Mar Pollut Bull 69:128-136. https://doi.org/ 10.1016/j.marpolbul.2013.01.016

Saleh Y (2016) Comparative life cycle assessment of beverages packages in Palestine. J Clean Prod 131:28-42. https://doi.org/10. 1016/j.jclepro.2016.05.080

Sarkar DJ, Das Sarkar S, Das BK et al (2019) Spatial distribution of meso and microplastics in the sediments of river Ganga at eastern India. Sci Total Environ 694:133712. https://doi.org/10.1016/j. scitotenv.2019.133712

Schuttlefield JD, Grassian VH (2008) ATR-FTIR spectroscopy in the undergraduate chemistry laboratory part I: fundamentals and examples. J Chem Educ 85:279-281. https://doi.org/10.1021/ ed085p279

Schwabl P, Koppel S, Konigshofer P et al (2019) Detection of various microplastics in human stool: a prospective case series. Ann Intern Med 171:453-457. https://doi.org/10.7326/M19-0618

Sevigné-Itoiz E, Gasol CM, Rieradevall J, Gabarrell X (2015) Contribution of plastic waste recovery to greenhouse gas (GHG) savings in Spain. Waste Manag 46:557-567. https://doi.org/10. 1016/j.wasman.2015.08.007

Sharon C, Sharon M (2013) Studies on biodegradation of polyethylene terephthalate: a synthetic polymer. J Microbiol Biotechnol Res $2: 248-257$ 
Shen L, Worrell E, Patel MK (2010) Open-loop recycling: a LCA case study of PET bottle-to-fibre recycling. Resour Conserv Recycl 55:34-52. https://doi.org/10.1016/j.resconrec.2010.06.014

Singha MK, Behera BK (2018) Effect of residual extensibility of polyester filament yarn on low-stress mechanical properties of fabric. Indian J Fibre Text Res 43:53-58

Sinha V, Patel MR, Patel JV (2010) PET waste management by chemical recycling: a review. J Polym Environ 18:8-25. https://doi.org/ 10.1007/s10924-008-0106-7

Sirohi S, Dobhal S, Doshi M et al (2019) Eco-friendly synthesis of PET-based polymeric plasticiser and its application in nitrilePVC rubber blends. Indian Chem Eng 61:206-217. https://doi. org/10.1080/00194506.2018.1529635

Song Y, Cao C, Qiu R et al (2019) Uptake and adverse effects of polyethylene terephthalate microplastics fibers on terrestrial snails (Achatina fulica) after soil exposure. Environ Pollut 250:447455. https://doi.org/10.1016/j.envpol.2019.04.066

Song YK, Hong SH, Jang M et al (2014) Large accumulation of microsized synthetic polymer particles in the sea surface microlayer. Environ Sci Technol 48:9014-9021. https://doi.org/10.1021/ es501757s

Sørensen L, Groven AS, Hovsbakken IA et al (2021) UV degradation of natural and synthetic microfibers causes fragmentation and release of polymer degradation products and chemical additives. Sci Total Environ 755:143170. https://doi.org/10.1016/j. scitotenv.2020.143170

Taniguchi I, Yoshida S, Hiraga K et al (2019) Biodegradation of PET: current status and application aspects. ACS Catal 9:4089-4105. https://doi.org/10.1021/acscatal.8b05171

Tekman MB, Krumpen T, Bergmann M (2017) Marine litter on deep Arctic seafloor continues to increase and spreads to the North at the Hausgarten observatory. Deep Res Part I Oceanogr Res Pap 120:88-99. https://doi.org/10.1016/j.dsr.2016.12.011

Thumarat U, Nakamura R, Kawabata T et al (2012) Biochemical and genetic analysis of a cutinase-type polyesterase from a thermophilic Thermobifida alba AHK119. ApplMicrobiolBiotechnol 95:419-430. https://doi.org/10.1007/s00253-011-3781-6

Tsochatzis ED, Alberto Lopes J, Kappenstein O et al (2020) Quantification of PET cyclic and linear oligomers in teabags by a validated LC-MS method-In silico toxicity assessment and consumer's exposure. Food Chem 317:126427. https://doi.org/10.1016/j. foodchem.2020.126427

Ubeda S, Aznar M, Nerín C (2018) Determination of oligomers in virgin and recycled polyethylene terephthalate (PET) samples by UPLC-MS-QTOF. Anal Bioanal Chem 410:2377-2384. https:// doi.org/10.1007/s00216-018-0902-4

Umamaheswari S, Murali M (2013) FTIR spectroscopic study of fungal degradation of poly (ethylene terephthalate) and polystyrene foam. Chem Eng 64:19159-19164

Vague M, Chan G, Roberts C et al (2019) Pseudomonas isolates degrade and form biofilms on polyethylene terephthalate (PET) plastic. bioRxiv 647321. https://doi.org/10.1101/647321

Van Der Velden NM, Patel MK, Vogtländer JG (2014) LCA benchmarking study on textiles made of cotton, polyester, nylon, acryl, or elastane. Int J Life Cycle Assess 19:331-356. https://doi.org/ 10.1007/s11367-013-0626-9

Vaverková M, Adamcová D, Kotrchová L et al (2018) Degradation of pet copolyesters under real and laboratory composting conditions. J Mater Cycles Waste Manag 20:414-420. https://doi.org/ 10.1007/s10163-017-0595-3

Venkatachalam S, Nayak SG, Labde JV, Gharal PR, Rao K, Kelkar AK (2012) Degradation and recyclability of poly (ethylene terephthalate). In: Polyester (pp 75-98). Rijeka, Croatia: InTech. https:// www.intechopen.com/chapters/39405

Vered G, Kaplan A, Avisar D, Shenkar N (2019) Using solitary ascidians to assess microplastic and phthalate plasticizers pollution among marine biota: a case study of the Eastern Mediterranean and Red Sea. Mar Pollut Bull 138:618-625. https://doi.org/10. 1016/j.marpolbul.2018.12.013

Vethaak AD, Leslie HA (2016) Plastic debris is a human health issue. Environ Sci Technol 50:6825-6826. https://doi.org/10.1021/acs. est.6b02569

van Emmerik T, Schwarz A (2020) Plastic debris in rivers. Wiley Interdiscip Rev Water 7(1):e1398. https://doi.org/10.1002/wat2.1398

Viana ME, Riul A, Carvalho GM et al (2011) Chemical recycling of PET by catalyzed glycolysis: kinetics of the heterogeneous reaction. Chem Eng J 173:210-219. https://doi.org/10.1016/j. cej.2011.07.031

Wakabayashi N, Kojima T, Funazukuri T (2012) Recovery of terephthalic acid and ethylene glycol from poly(ethylene terephthalate) under hydrothermal conditions of aqueous trimethylamine solution. Ind Eng Chem Res 51:5699-5704. https://doi.org/10.1021/ ie202885u

Wang Y, Wang X, Lu W et al (2019a) A thin film polyethylene terephthalate (PET) electrochemical sensor for detection of glucose in sweat. Talanta 198:86-92. https://doi.org/10.1016/j.talanta. 2019.01.104

Wang Y, Wang Y (2004) Study on the hydrolysis-resistant polyethylene terephthalate (PET) fibers. In: Composites technologies for 2020. Woodhead Publishing Limited, pp 78-82. https://doi.org/ 10.1533/9781845690625.18.1039

Wang Y, Zhang Y, Song H et al (2019b) Zinc-catalyzed ester bond cleavage: chemical degradation of polyethylene terephthalate. J Clean Prod 208:1469-1475. https://doi.org/10.1016/j.jclepro. 2018.10.117

Webb HK, Arnott J, Crawford RJ, Ivanova EP (2013) Plastic degradation and its environmental implications with special reference to poly(ethylene terephthalate). Polymers (basel) 5:1-18. https:// doi.org/10.3390/polym5010001

Wei R, Breite D, Song C et al (2019) Biocatalytic degradation efficiency of postconsumer polyethylene terephthalate packaging determined by their polymer microstructures. Adv Sci 6(14):1900491. https://doi.org/10.1002/advs.201900491

Wei R, Oeser T, Then J et al (2014) Functional characterization and structural modeling of synthetic polyester-degrading hydrolases from Thermomonospora curvata. AMB Express 4:1-10. https:// doi.org/10.1186/s13568-014-0044-9

Welle F (2016) Investigation into cross-contamination during cleaning efficiency testing in PET recycling. Resour Conserv Recycl 112:65-72. https://doi.org/10.1016/j.resconrec.2016.05.003

Whitt M, Brown W, Danes JE, Vorst KL (2016) Migration of heavy metals from recycled polyethylene terephthalate during storage and microwave heating. J Plast Film Sheeting 32:189-207. https://doi.org/10.1177/8756087915590190

Wierckx N, Prieto MA, Pomposiello P et al (2015) Plastic waste as a novel substrate for industrial biotechnology. Microb Biotechnol 8:900-903. https://doi.org/10.1111/1751-7915.12312

Williams TGJL, Heidrich O, Sallis PJ (2010) A case study of the openloop recycling of mixed plastic waste for use in a sports-field drainage system. Resour Conserv Recycl 55:118-128. https:// doi.org/10.1016/j.resconrec.2010.08.002

Willis K, Denise Hardesty B, Kriwoken L, Wilcox C (2017) Differentiating littering, urban runoff and marine transport as sources of marine debris in coastal and estuarine environments. Sci Rep 7(1):1-9. https://doi.org/10.1038/srep44479

Xia J, Huang Y, Li Q et al (2021) Convolutional neural network with near-infrared spectroscopy for plastic discrimination. Environ Chem Lett 19:3547-3555. https://doi.org/10.1007/ s10311-021-01240-9

Yaka M, Ehirchiou A, Alkandry TTS, Sair K (2015) Huge plastic bezoar: a rare cause of gastrointestinal obstruction. Pan Afr Med J 21:1-5. https://doi.org/10.11604/pamj.2015.21.286.7169 
Yoshida S, Hiraga K, Takehana T et al (2016) A bacterium that degrades and assimilates poly(ethylene terephthalate). Science 80(351):1196-1199. https://doi.org/10.1126/science.aad6359

Young AM, Elliott JA (2016) Characterization of microplastic and mesoplastic debris in sediments from Kamilo Beach and Kahuku Beach, Hawai'i. Mar Pollut Bull 113:477-482. https://doi.org/10. 1016/j.marpolbul.2016.11.009

Yu X, Ladewig S, Bao S et al (2018) Occurrence and distribution of microplastics at selected coastal sites along the southeastern United States. Sci Total Environ 613-614:298-305. https://doi. org/10.1016/j.scitotenv.2017.09.100

Zair MMB, Jakarni FM, Muniandy R, Hassim S (2021) A brief review: application of recycled polyethylene terephthalate in asphalt pavement reinforcement. Sustainability 13(3):1303. https://doi. org/10.3390/su13031303

Zbyszewski M, Corcoran PL (2011) Distribution and degradation of fresh water plastic particles along the beaches of Lake Huron, Canada. Water Air Soil Pollut 220:365-372. https://doi.org/10. 1007/s11270-011-0760-6

Zhang C, Zhou H, Cui Y et al (2019) Microplastics in offshore sediment in the Yellow Sea and East China Sea, China. Environ
Pollut 244:827-833. https://doi.org/10.1016/j.envpol.2018.10. 102

Zhang W, Ma X, Zhang Z et al (2015) Persistent organic pollutants carried on plastic resin pellets from two beaches in China. Mar Pollut Bull 99:28-34. https://doi.org/10.1016/j.marpolbul.2015. 08.002

Zhang XX, Sun SL, Zhang Y et al (2010) Toxicity of purified terephthalic acid manufacturing wastewater on reproductive system of male mice (Mus musculus). J Hazard Mater 176:300-305. https:// doi.org/10.1016/j.jhazmat.2009.11.028

Zhou X, Wang C, Fang C et al (2019) Structure and thermal properties of various alcoholysis products from waste poly(ethylene terephthalate). Waste Manag 85:164-174. https://doi.org/10.1016/j. wasman.2018.12.032

Publisher's Note Springer Nature remains neutral with regard to jurisdictional claims in published maps and institutional affiliations. 